\title{
Synthesis of soluble oligothiophenes bearing cyano groups, their optical and electrochemical properties
}

\author{
Jean-Yves Balandier ${ }^{\mathrm{a}}$, Florence Quist ${ }^{\mathrm{a}}$, Claire Amato ${ }^{\mathrm{a}}$, Saïd Bouzakraoui ${ }^{\mathrm{b}}$, Jérôme Cornil ${ }^{\mathrm{b}}$, \\ Sergey Sergeyev ${ }^{\mathrm{a}, \mathrm{c}}$, Yves Geerts ${ }^{\mathrm{a}, *}$ \\ a Université Libre de Bruxelles (ULB), Faculté des sciences, Laboratoire Chimie des Polymères, CP 206/1, Boulevard du triomphe, 1050 Brussels, Belgium \\ ${ }^{\mathrm{b}}$ Laboratory for Chemistry of Novel Materials, University of Mons (UMons), Place du Parc 20, 7000 Mons, Belgium \\ ${ }^{\mathrm{c}}$ University of Antwerp, Department of Chemistry, Groenenborgerlaan 171, 2020 Antwerp, Belgium
}

\section{A R T I C L E I N F O}

\section{Article history:}

Received 15 July 2010

Received in revised form 21 September 2010

Accepted 28 September 2010

\section{Keywords:}

Oligothiophene synthesis

$n$-Type semiconductors

Organic electronics

Cyclic voltammetry

\begin{abstract}
A B S T R A C T
The synthesis and the characterization of twelve new soluble oligothiophenes, possessing two to four 3,4dicyanothiophene units in their backbone, are described. These semiconductors are prepared through Stille coupling and/or homo-coupling reactions. Cyclic voltammetry studies have been performed to evaluate their stability as $n$-type semiconducting materials under ambient conditions. The measured electrochemical and optical properties are fully supported by quantum-chemical calculations.
\end{abstract}

(c) 2010 Elsevier Ltd. All rights reserved.

\section{Introduction}

Over several decades, many studies have been reported in the literature on uses of organic semiconductors in a variety of devices, such as field effect transistors (FETs), light-emitting diodes (LED), and photovoltaic cells (PV). ${ }^{1-6}$ The unique properties of these organic semiconducting materials make them more attractive than their inorganic counterparts for applications requiring large area coverage, structural flexibility, and/or solution processing. Two types of charge transport are considered in the field of organic electronic: $p$-type (hole-transporting) and $n$-type (electron-transporting). ${ }^{7}$ Contrary to $p$-type semiconductors, which are welldocumented and have shown highly promising electronic properties, ${ }^{2,8}$ studies on organic $n$-type semiconductors are still limited due to their instability in ambient conditions, ${ }^{9}$ although recent improvement have been made. ${ }^{10}$

Recently, Facchetti and co-workers have demonstrated that semiconductors possessing their first reduction potential between $-0.6 \mathrm{~V}$ and $0.0 \mathrm{~V}$ (vs Standard Calomel Electrode, SCE) feature the ambient conditions stability needed for organic-FETs (OFETs) operating in $n$-type mode. ${ }^{11}$ Inspired by their work, we were interested in building a library of soluble semiconducting molecules

\footnotetext{
* Corresponding author. Tel.: +32 2650 5390; fax: +32 265054 10; e-mail address: ygeerts@ulb.ac.be (Y. Geerts).
}

and in measuring their reduction potentials, as it is currently one of the most direct ways of assessing the prospective stability of $n$-type semiconducting materials.

One main approach for building $n$-type semiconducting molecules consists in including electron-withdrawing units on an aromatic backbone, in order to increase the electron affinity. ${ }^{12}$ For example, Facchetti and co-workers have synthesized a series of oligothiophenes showing high electron affinity through the incorporation of perfluoroalkyl groups. ${ }^{13}$ Similarly to perfluoroalkyl chains, the cyano group is known as a strong electron-withdrawing group; however its use for the construction of oligothiophene based $n$-type semiconductors remains limited. ${ }^{14-19}$ In this context, we were interested in the synthesis of a series of new soluble electron-deficient conjugated systems based on cyano-substituted oligothiophenes (Scheme 1). In order to satisfy solubility requirements, the number of cyano groups was limited to a maximum of 4 , since cyano substituents are known to decrease solubility, ${ }^{20}$ and alkyl or keto-alkyl side chains were introduced. Keto-functions should enhance the electron affinity of target oligothiophenes even more due to their electron-withdrawing character. The optical and electrochemical properties of these newly synthesized semiconducting molecules were then evaluated and rationalized by means of quantum-chemical calculations. The goal pursued here is to elucidate reliable relationships between molecular structure and electron affinity in order to establish design rules for $n$-type organic semiconductors. 


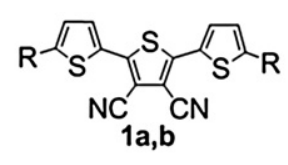<smiles>[R]c1sc(-c2[R9]cc(-c3sc([R])c(C#N)c3C)s2)cc1C#N</smiles><smiles>[R]C(=O)c1sc(-c2sc([R])c(C#N)c2N)c(C#N)c1N</smiles>

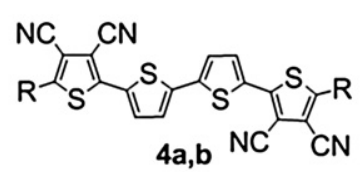

$2 a, b$<smiles>[N]</smiles>

NC $\mathrm{CN}^{3 a, b}$ $\mathrm{CN}$

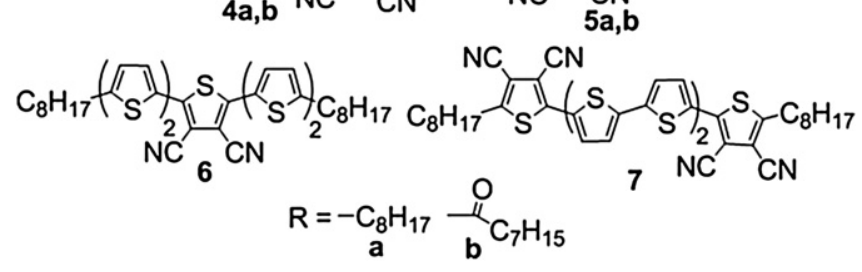

Scheme 1. Target oligothiophene derivatives bearing cyano groups.

\section{Results and discussion}

\subsection{Synthesis}

Generally, there are four methods reported in the literature for the synthesis of oligothiophene derivatives: (i) Kumada crosscoupling of an aromatic Grignard reagent and an aromatic halide, (ii) Suzuki coupling between an aromatic boronic ester and an aromatic halide, (iii) Stille coupling between an aromatic stannane and an aromatic halide, and (iv) homo-coupling of an aromatic halide. ${ }^{21}$ Throughout this work, Stille coupling and homo-coupling were applied for the synthesis of oligothiophenes to avoid possible synthetic problems. It is indeed known that Grignard reagents, involved in Kumada coupling, can react with cyano groups at room temperature to afford anionic imines, which are then transformed into ketones through hydrolysis. ${ }^{22}$ Furthermore, Stille coupling is known to produce better yields compared to Suzuki coupling in oligothiophene synthesis. ${ }^{21}$ Homo-coupling was used to prepare the even-numbered oligothiophenes (3a,b, $\mathbf{4 a}, \mathbf{b}, \mathbf{5 a}, \mathbf{b}$, and $\mathbf{7}$ ) as these can be easily reached in one step starting from the halogenated subunit corresponding to half of the oligothiophene.

2.1.1. Synthesis of terthiophenes $\mathbf{1 a}, \boldsymbol{b}$. The first synthetic steps toward oligothiophenes 1a,b, involved the preparation of 2,5dibromo-3,4-dicyanothiophene (10), 2,5-bis(tributylstannyl)-3,4dicyanothiophene (11), and 2-octyl-5-tributylstannylthiophene (15) intermediates (Scheme 2). Preparation of $\mathbf{1 0}$ was achieved through cyanation of 3,4-dibromothiophene (8) using $\mathrm{CuCN}$ in refluxing DMF, yielding 3,4-dicyanothiophene (9) in $72 \%$ yield. ${ }^{23-25}$

The second step consisted of the dibromination of 3,4-dicyanothiophene (9) to afford $\mathbf{1 0}$. Several attempts to synthesize brominated derivatives of 3,4-dicyanothiophene (9) using NBS or $\mathrm{Br}_{2}$ in $\mathrm{CHCl}_{3}$ under reflux, were made. However, these experiments were found unsatisfactory as starting material was always quantitatively recovered. The lack of reactivity was attributed to the deactivation of the thiophene ring due to the presence of highly electronwithdrawing $-\mathrm{CN}$ groups. Hence, an alternate synthetic route was followed in which, first lithiation of $\mathbf{9}$ with an excess of LDA was performed, followed by a reaction with bromine. Dibrominated derivative $\mathbf{1 0}$ was obtained in good yields (62\%). At this stage, it is also important to note that all metalation reactions, involving oligothiophene bearing CN groups, were carried out using LDA instead of alkyllithium derivatives ( $n$-BuLi, sec-BuLi, tert-BuLi) to prevent a nucleophilic addition of these strong bases to cyano groups. ${ }^{18}$ Compound $\mathbf{1 1}$ was obtained in 79\% yield, by lithiation of $\mathbf{9}$ with LDA, followed by reaction with tributylstannyl chloride. Compound 15 was produced with overall yield of $47 \%$, starting from commercial thiophene and using synthetic procedures previously described in the literature. ${ }^{26}$ Stille coupling between 2-octyl-5-tributylstannylthiophene (15) and 2,5-dibromo-3,4-dicyanothiophene (10) afforded terthiophene 1a in $60 \%$ yield. Preparation of terthiophene 1b was achieved in two steps starting from $\mathbf{1 0}$. Two routes were investigated to synthesize the intermediate terthiophene $\mathbf{1 2}$. The first one involved a Stille coupling between product $\mathbf{1 1}$ and commercial 2-bromothiophene. In this case, it was impossible to reach the desired $3^{\prime}, 4^{\prime}$-dicyano- $2,2^{\prime}: 5^{\prime}, 2^{\prime \prime}$-terthiophene (12), since the degradation of the medium was noticed. This observation seems to indicate that it will be certainly difficult to prepare fully cyanated oligothiophene. Terthiophene $\mathbf{1 2}$ was finally synthesized with a yield of $93 \%$ through a second Stille coupling between commercial 2-(tributylstannyl)thiophene and 2,5-dibromo-3,4-dicyanothiophene (10). Compound 12 was then converted into terthiophene $\mathbf{1 b}$ in 55\% yield through a double Friedel-Crafts acylation (Scheme 2). During that second step, a significant amount of mono acylated compound $13(20 \%)$ was isolated even after long reaction times and use of large excess of reagents $\left(\mathrm{AlCl}_{3}\right.$ and octanoyl chloride). Monitoring this reaction showed the complete conversion of the starting oligothiophene into $\mathbf{1 3}$ (product of mono acylation) after $12 \mathrm{~h}$. It was further noticed that the second acylation is very slow and remains incomplete after ten days at refluxing in $\mathrm{CH}_{2} \mathrm{Cl}_{2}$. Such behavior was ascribed to the deactivation of the terthiophene core due to the presence of strongly electron-withdrawing groups (two $\mathrm{CN}$ groups and one keto-alkyl chain).

2.1.2. Synthesis of terthiophenes $\mathbf{2 a}, \boldsymbol{b}$. Terthiophenes $\mathbf{2 a , b}$ were synthesized by Stille coupling between 2,5-bis(tributylstannyl)

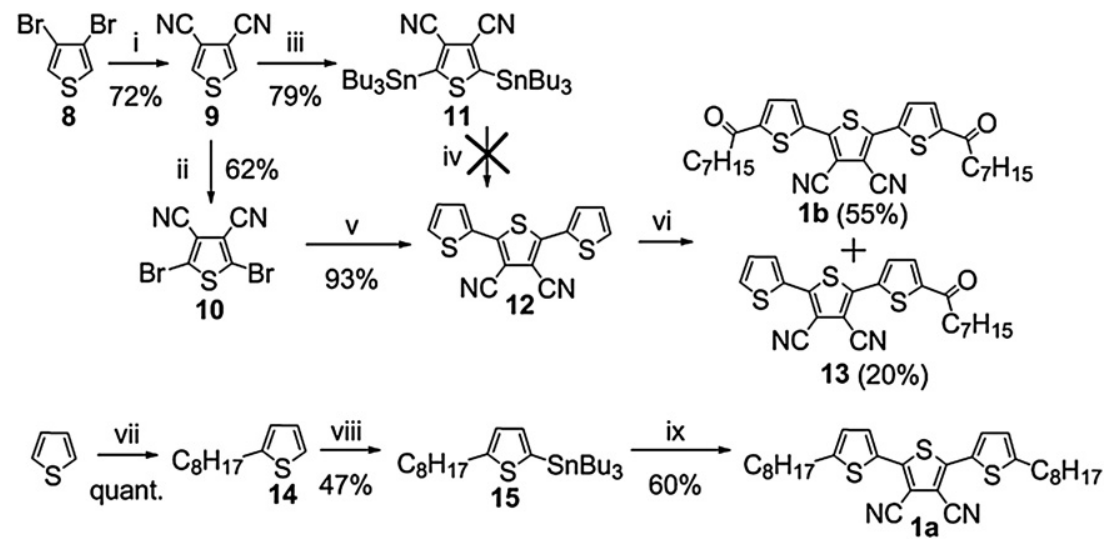

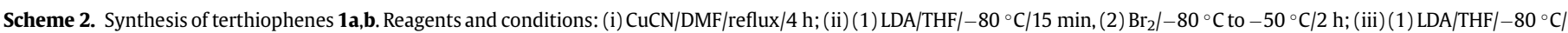

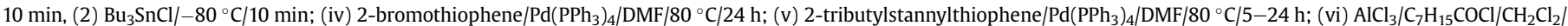
reflux/10 days; (vii) (1) $n$-BuLi/THF/ $-80{ }^{\circ} \mathrm{C} / 15 \mathrm{~min}$, (2) $\mathrm{C}_{8} \mathrm{H}_{17} \mathrm{I} /-80^{\circ} \mathrm{C}$ to rt/overnight; (viii) (1) $\mathrm{LDA} / \mathrm{THF} /-80{ }^{\circ} \mathrm{C} / 5 \mathrm{~min},(2) \mathrm{Bu} \mathrm{SnCl} /-80{ }^{\circ} \mathrm{C} / 1 \mathrm{~h}$; (ix) $10 / \mathrm{Pd}(\mathrm{PPh})_{4} / \mathrm{DMF} / 80{ }^{\circ} \mathrm{C} / 5 \mathrm{~h}$. 


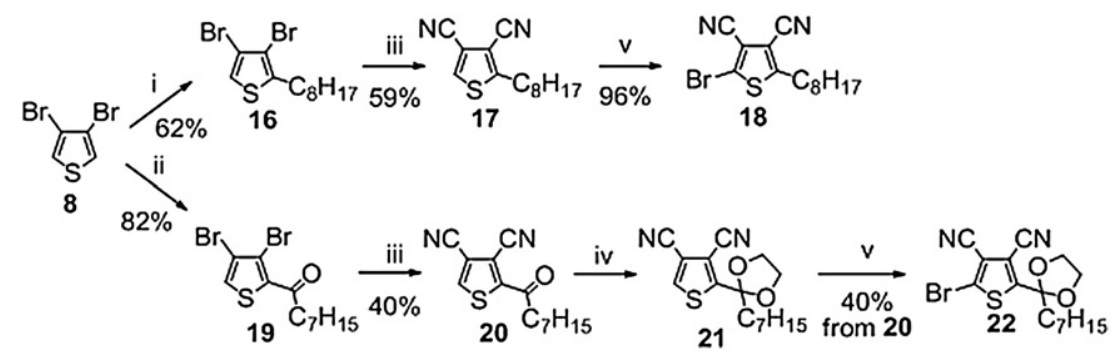

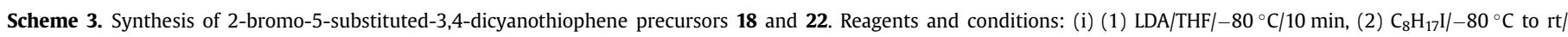

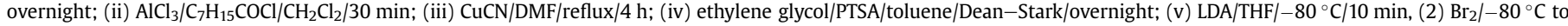
$-50{ }^{\circ} \mathrm{C} / 30 \mathrm{~min}$.

thiophene $(\mathbf{2 3})^{27}$ and 2-bromo-5-substituted-3,4-dicyanothiophene precursors $\mathbf{1 8}$ and $\mathbf{2 2}$. The synthetic routes for the preparation of compounds $\mathbf{1 8}$ and $\mathbf{2 2}$ starting from 3,4-dibromothiophene (8) are shown in Scheme 3. The alkylated compound $\mathbf{1 6}$ was prepared in $62 \%$ yield following a procedure described for the synthesis of 2-isopropyl-3,4-dibromothiophene, ${ }^{28}$ via metalation of $\mathbf{8}$ using LDA, followed by reaction of the corresponding organolithium intermediate with 1-iodooctane. 2-Octanoyl-3,4-dibromothiophene (19) was obtained by a Friedel-Crafts acylation of 8 using conditions previously described in the literature. ${ }^{29}$ Compounds 16 and 19 were then converted into 3,4-dicyanothiophene derivatives 17 and 20, respectively, through cyanation with copper cyanide in refluxing DMF. ${ }^{23-25}$ Similar bromination conditions to those used in the preparation of $\mathbf{1 0}$ ( $\mathrm{LDA}$ then $\mathrm{Br}_{2}$ ) were used for the synthesis of $\mathbf{1 8}$ and the latter compound was obtained in $96 \%$ yield. In the case of compound 20, the protection of its keto-function was needed to avoid side reaction which could occur with the use of LDA. It was executed by reaction of 2-octanoyl-3,4-dicyanothiophene (20) with ethylene glycol, in the presence of $p$-toluenesulfonic acid monohydrate. The protected derivative $\mathbf{2 1}$ was then converted into 2-bromo-5-substituted-3,4-dicyanothiophene 22 ( $40 \%$ yield from 20 ) by successive reactions with LDA and bromine.

Finally, oligothiophenes 2a,b were synthesized by two-fold Stille coupling between stannyl derivatives $\mathbf{2 3}$ and compounds $\mathbf{1 8}$ and 22 (Schemes 4 and 5).

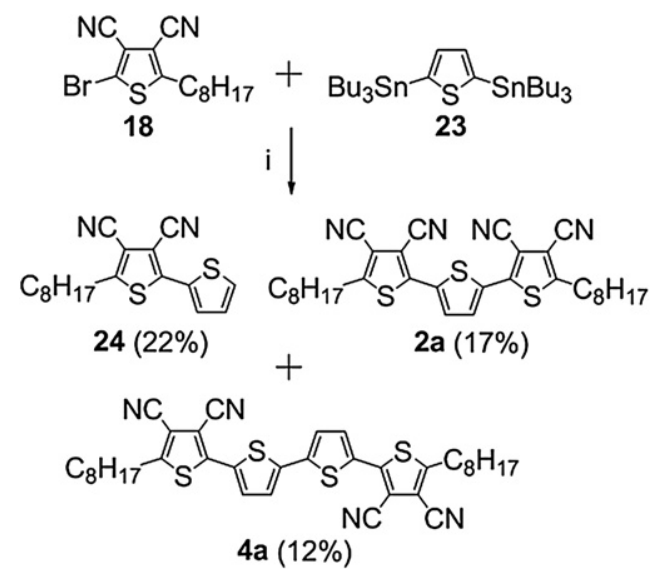

Scheme 4. Synthesis of terthiophene 2a. Reagents and conditions: (i) $\mathrm{Pd}\left(\mathrm{PPh}_{3}\right)_{4} /$ toluene $/ 105^{\circ} \mathrm{C} /$ overnight.

In the case of the terthiophene $\mathbf{2 b}$, a last step of deprotection of the ketone groups was needed, which was performed using acidic resin Amberlyst ${ }^{\circledR}$ A15 in dichloromethane. ${ }^{30}$

The low yields observed for both compounds $\mathbf{2 a}$ (17\%) and $\mathbf{2 b}$ (10\%) are ascribed to the formation of side products, bithiophenes $\mathbf{2 4}$ and 26 as well as quaterthiophenes $\mathbf{4 a}$ and $\mathbf{2 5}$, during the Stille coupling reactions. While the formation of compounds $\mathbf{2 4}$ and $\mathbf{2 6}$

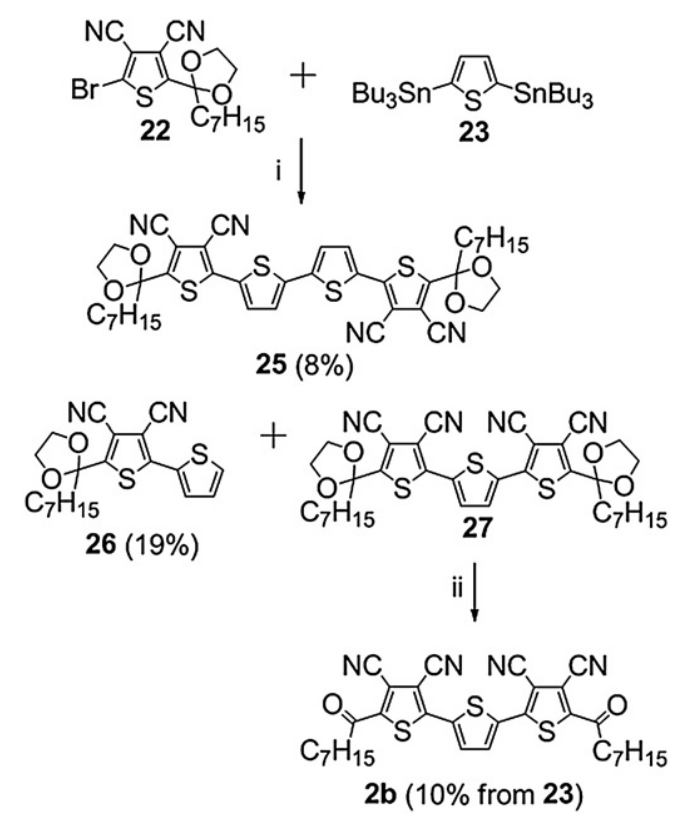

Scheme 5. Synthesis of terthiophene 2a. Reagents and conditions: (i) $\mathrm{Pd}\left(\mathrm{PPh}_{3}\right)_{4} /$ toluene/105 ${ }^{\circ} \mathrm{C} /$ overnight; Amberlyst ${ }^{\circledR} \mathrm{A} 15 / \mathrm{CH}_{2} \mathrm{Cl}_{2} / \mathrm{rt} /$ overnight.

can be attributed to the degradation of the corresponding tin intermediates produced after one Stille coupling of $\mathbf{1 8} / \mathbf{2 2}$ with $\mathbf{2 3}$, the formation of $\mathbf{4 a}$ and $\mathbf{2 5}$ most probably results from the homocoupling of these same tin intermediates produced after one Stille coupling. Homo-coupling of tin derivatives has indeed previously been reported in the literature. ${ }^{31}$ Optimisation of the reaction conditions for the formation of $\mathbf{2 a}$ by changing the solvent, the catalyst or by reducing the reaction temperature was attempted (Table 1) without success. No noticeable change was indeed observed by substituting $\mathrm{Pd}\left(\mathrm{PPh}_{3}\right)_{4}$ with $\mathrm{Cl}_{2} \mathrm{Pd}\left(\mathrm{PPh}_{3}\right)_{2}$ (entry 2, Table 1). In addition, no reaction occurred when the reaction temperature was decreased from $105^{\circ} \mathrm{C}$ to $80^{\circ} \mathrm{C}$ (entry 1, Table 1) and only decomposition of the medium was observed by changing the solvent from toluene to DMF (entry 3, Table 1 ).

Table 1

Attempted variation of reaction conditions for the formation of $\mathbf{2 a}$

\begin{tabular}{lllcl}
\hline Entry & catalyst & Solvent & Temperature ${ }^{\circ} \mathrm{C}$ & Yield (\%) \\
\hline 1 & $\mathrm{Pd}\left(\mathrm{PPh}_{3}\right)_{4}$ & Toluene & 80 & No reaction \\
2 & $\mathrm{Cl}_{2} \mathrm{Pd}_{\left(\mathrm{PPh}_{3}\right)_{2}}$ & Toluene & 105 & 15 \\
3 & $\mathrm{Pd}\left(\mathrm{PPh}_{3}\right)_{4}$ & DMF & 105 & Decomposition \\
\hline
\end{tabular}

2.1.3. Synthesis of bithiophenes $3 \boldsymbol{a}, \boldsymbol{b}$. 3,3',4,4'-Tetracyano-2,2'bithiophenes $\mathbf{3 a}$ and $\mathbf{3 b}$ were prepared by Pd-catalyzed homocoupling of compounds $\mathbf{1 8}$ and $\mathbf{2 2}$, respectively (Scheme 6). ${ }^{32}$ In case of bithiophene $\mathbf{3 b}$, deprotection of the ketone groups was 

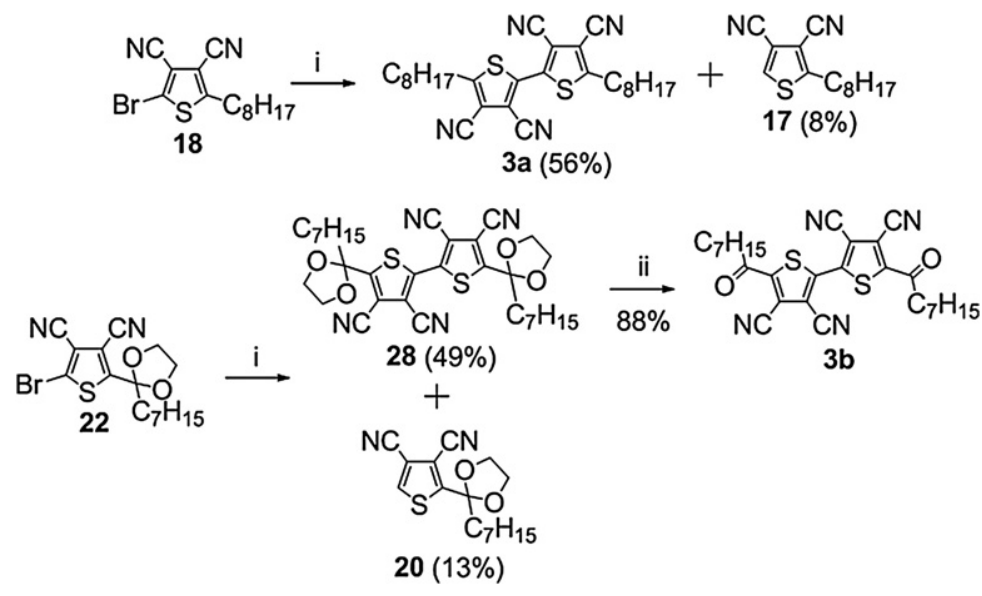

Scheme 6. Synthesis of bithiophenes 3a,b. Reagents and conditions: (i) $\mathrm{Pd}(\mathrm{OAc})_{2} / i-\mathrm{Pr}_{2} \mathrm{EtN} /$ toluene/reflux $/ 2$ h; (ii) $\mathrm{Amberlyst}{ }^{\circledR} \mathrm{A} 15 / \mathrm{CH}_{2} \mathrm{Cl}_{2} / \mathrm{overnight}$.

needed and it was performed using the same conditions as described for $\mathbf{2 b}$. Modest yields were observed for both compounds ( $56 \%$ for $\mathbf{3 a}$ and $43 \%$ (overall yield) for $\mathbf{3 b}$ ) and this was ascribed to the debromination of $\mathbf{1 8}$ and $\mathbf{2 2}$ during the homo-coupling reaction. Such a process has already been reported in literature ${ }^{32}$ and was confirmed after isolation of derivatives $\mathbf{1 7}(8 \%)$ and $\mathbf{2 0}(13 \%)$ by column chromatography, during the purification of bithiophenes 3a and 28.

2.1.4. Synthesis of quaterthiophenes $\mathbf{4 a}, \boldsymbol{b}$. Synthesis of quaterthiophenes $\mathbf{4 a , b}$ was carried out by Pd-catalyzed homo-coupling of their corresponding brominated bithiophene units (Scheme 7). Stille coupling between 2-(tributylstannyl)thiophene and compounds $\mathbf{1 8}$ or $\mathbf{2 2}$, initially generated bithiophenes $\mathbf{2 4}$ and $\mathbf{2 6}$ in excellent yields (93\% and $87 \%$, respectively). These were then selectively brominated in position $5^{\prime}$ through an electrophilic substitution reaction with bromine to yield intermediates $\mathbf{2 9}$ and $\mathbf{3 0}$. Bromination of $\mathbf{2 6}$ was performed in the presence of triethylamine, to avoid deprotection of the ketone function, which could occur due to the formation of $\mathrm{HBr}$ during the reaction. Finally, palladium catalyzed reaction in homocoupling conditions of derivatives $\mathbf{2 9}$ and $\mathbf{3 0}$ gave quaterthiophenes 4a and 25, respectively, in good yields (51\% and $49 \%$ ). Similarly to the synthesis of oligothiophenes $\mathbf{3 a}, \mathbf{b}$, the modest yields observed were attributed to the formation of bithiophenes $\mathbf{2 4}$ (12\%) and $\mathbf{2 6}$ (8\%), formed by the debromination of the starting halogenated compounds 29 and 30. Finally, deprotection of $\mathbf{2 5}$ using acidic resin Amberlyst ${ }^{\circledR}$ A15 in dichloromethane afforded oligothiophene $\mathbf{4 b}$ in $81 \%$ yield. $^{30}$ bithiophene units (Scheme 9). Initially, compound $\mathbf{3 1}$ was prepared by lithiation of 3,4-dicyanothiophene (9) using 1 equiv of LDA followed by the reaction with bromine (Scheme 8). It was however noticed that such pathway systematically resulted in a mixture of compounds 31 (35\% yield) with 3,4-dicyanothiophene (9) (21\% yield) and 2,5-dibromo-3,4-dicyanothiophene (10) (24\% yield), which were difficult to separate by column chromatography.

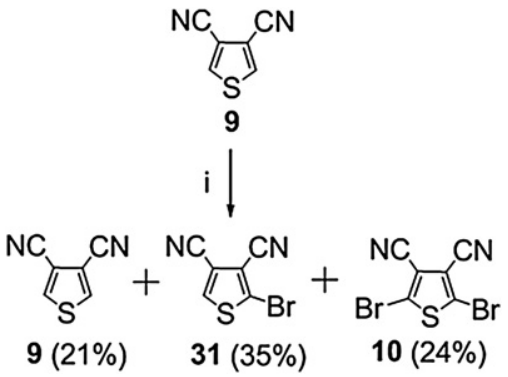

Scheme 8. Bromination of thiophene 9. Reagents and conditions: (i) LDA/THF/ $-80^{\circ} \mathrm{C} /$ $10 \mathrm{~min},(2) \mathrm{Br}_{2} /-80^{\circ} \mathrm{C}$ to rt.

Therefore, different strategy was employed. Xie and co-workers demonstrated the possibility to synthesize, through a catalytic reduction, several bromothiophenes starting from tetrabromothiophene. ${ }^{33}$ Inspired by this work, compound 10 was converted into 2-bromo-3,4-dicyanothiophene (31) in 71\% yield (Scheme 9). In a second step, Stille coupling of intermediate $\mathbf{3 1}$ with either 2-octyl-
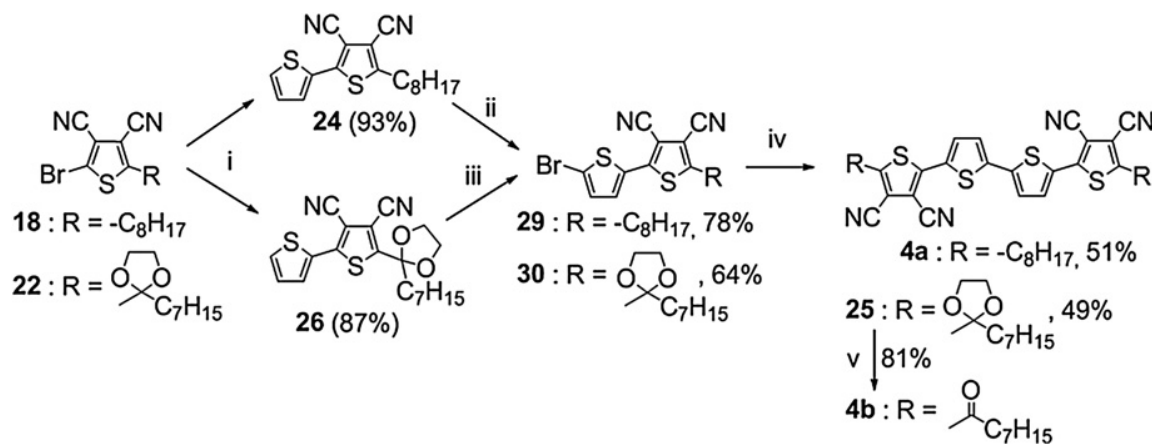


$\mathrm{CH}_{2} \mathrm{Cl}_{2} / \mathrm{rt} / 2 \mathrm{~h} ; \mathrm{Pd}(\mathrm{OAc})_{2} /$ diisopropylethylamine/toluene/reflux/2.5 h-4.5 h; (iv) Amberlyst ${ }^{\circledR} \mathrm{A} 15 / \mathrm{CH}_{2} \mathrm{Cl}_{2} / \mathrm{rt} /$ overnight.

2.1.5. Synthesis of quaterthiophenes $\mathbf{5 a}, \boldsymbol{b}$. Similarly to quaterthiophenes $\mathbf{4 a}, \mathbf{b}$, synthesis of quaterthiophenes $\mathbf{5 a}, \mathbf{b}$ was executed by homo-coupling reactions of their corresponding brominated 5-tributylstannylthiophene (15) or 2-tributylstannylthiophene provided bithiophenes $\mathbf{3 2}$ and 34, respectively. Compound $\mathbf{3 2}$ was then brominated through lithiation with LDA followed by the reaction 


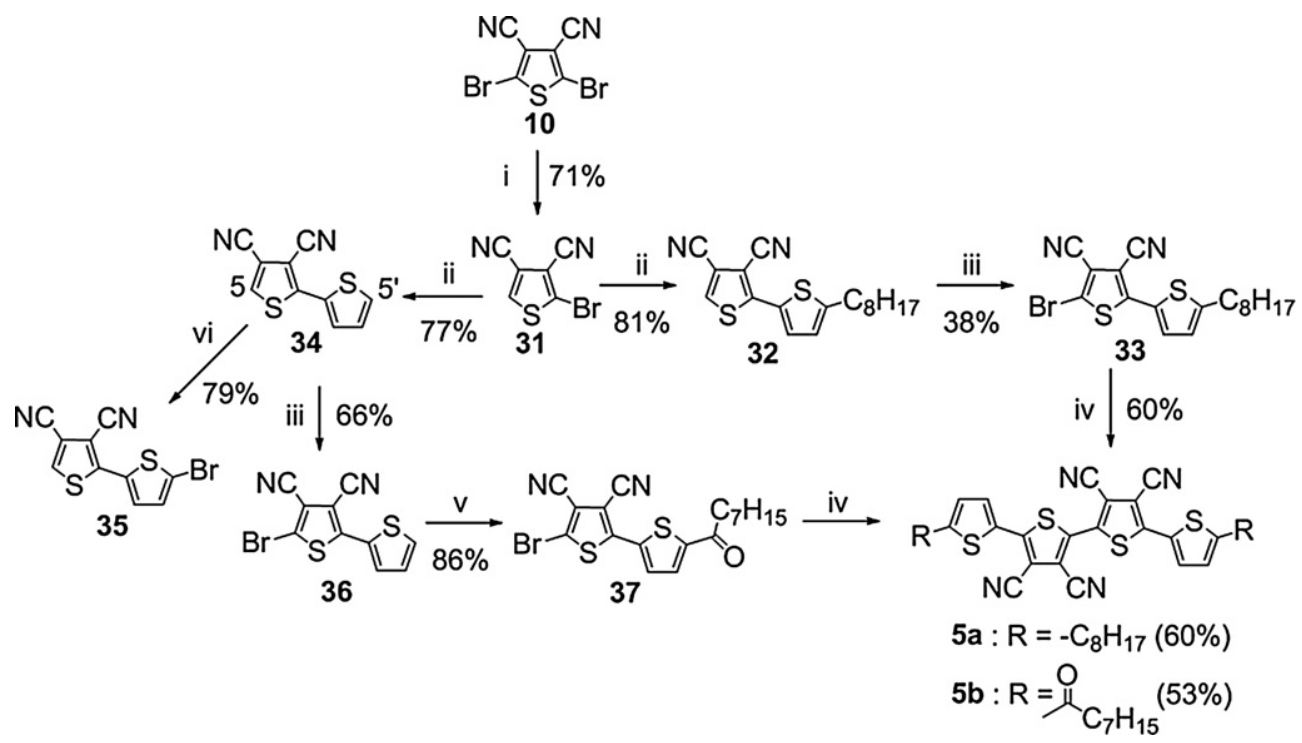

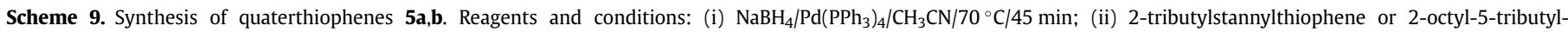

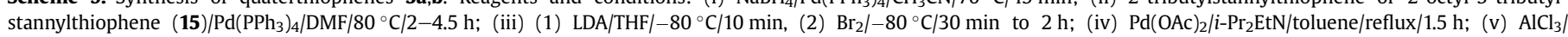
$\mathrm{C}_{7} \mathrm{H}_{15} \mathrm{COCl} / \mathrm{CH}_{2} \mathrm{Cl}_{2} /$ reflux/3 days; (vi) $\mathrm{Br}_{2} / \mathrm{CH}_{2} \mathrm{Cl}_{2} / \mathrm{rt} / 35$ min.

with bromine to give product 33. Pd-catalyzed homo-coupling of the latter afforded the desired quaterthiophene $\mathbf{5 a}$ in good yield (60\%).

Due to different reactivities of positions 5 and $5^{\prime}$, bithiophene 34 appears as an interesting building block. The proton in position 5 should be more acidic, due to the proximity of two CN groups than the one in position $5^{\prime}$. This implies that position 5 should be more sensitive to deprotonation, whereas position $5^{\prime}$ should be prone to electrophilic substitution. These hypotheses were confirmed by the synthesis of compound 35 by the reaction of $\mathbf{3 4}$ with bromine and by the preparation of compound $\mathbf{3 6}$ through successive deprotonation in position 5 of $\mathbf{3 4}$ with LDA and reaction with bromine. Intermediate $\mathbf{3 6}$ was then acylated through Friedel-Crafts reaction with octanoyl chloride to afford bithiophene 37. This step further confirms the specific reactivities of positions 5 and $5^{\prime}$ in compound 34 .

In a final step, homo-coupling reaction of derivative $\mathbf{3 7}$ led to the desired oligothiophene $\mathbf{5 b}$ in good yield (53\%). It should be noted that contrary to the synthesis of oligothiophenes $\mathbf{3 a}, \mathbf{b}$ and $\mathbf{4 a , b}$ via homo-coupling pathway, no side products originating from the debromination of starting bithiophene $\mathbf{3 3}$ and $\mathbf{3 7}$ were detected.

2.1.6. Synthesis of quinquethiophene 6 and sexithiophene 7. Two additional oligothiophenes, $\mathbf{6}$ and 7, having more extended $\pi$ systems have been synthesized using Stille coupling or homo-coupling

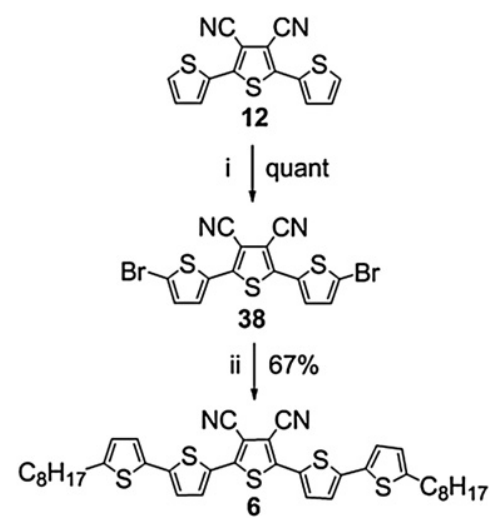

Scheme 10. Synthesis of quinquethiophene 6. Reagents and conditions: (i) $\mathrm{Br}_{2} / \mathrm{CH}_{2} \mathrm{Cl}_{2} /$ $\mathrm{rt} / 1.5 \mathrm{~h}$; (ii) 2-octyl-5-tributylstannylthiophene (15)/Pd( $\left(\mathrm{PPh}_{3}\right)_{4} / \mathrm{DMF} / 70^{\circ} \mathrm{C} / 4.5 \mathrm{~h}$. reactions in a few additional steps. Quinquethiophene 6 was obtained in two steps starting from terthiophene $\mathbf{1 2}$ following the route shown in Scheme 10. In a first step, 12 was quantitatively brominated in positions 5 and $5^{\prime \prime}$ by electrophilic substitution with $\mathrm{Br}_{2}$. Derivative 38 was then used in a double Stille coupling reaction with 2-octyl-5-tributylstannylthiophene (15) to provide oligothiophene $\mathbf{6}$ in $67 \%$ yield.

Sexithiophene $\mathbf{7}$ was prepared in three steps starting from bithiophene $\mathbf{2 9}$ (Scheme 11). A Stille coupling between bithiophene 29 and 2-tributylstannylthiophene afforded terthiophene 39 in 94\% yield. Compound 39 was then brominated in position $5^{\prime \prime}$ using NBS (NBS instead of $\mathrm{Br}_{2}$ was used in order to avoid the bromination of the middle thiophene unit). Finally, homo-coupling reaction of terthiophene $\mathbf{4 0}$ afforded sexithiophene $\mathbf{7}$. The low yield of this last step (11\%) is explained by the formation of derivative 39 (34\%

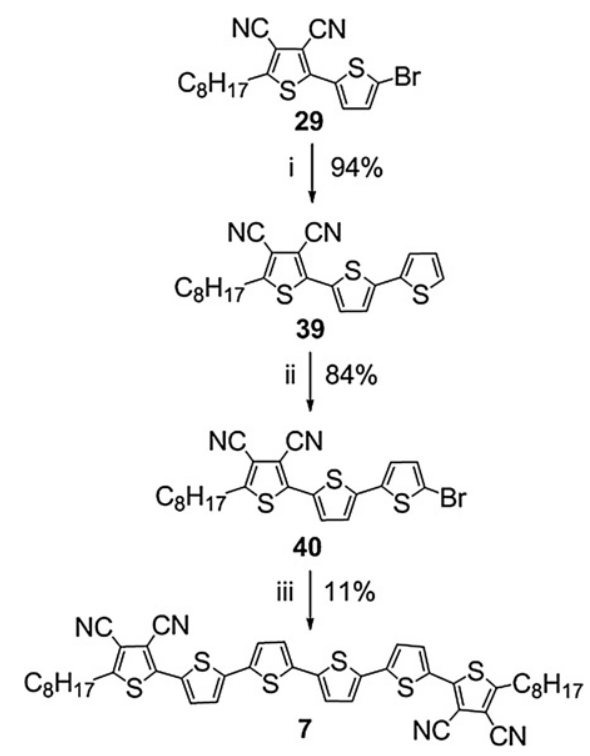

Scheme 11. Synthesis of sexithiophene 7. Reagents and conditions: (i) 2-tributylstannylthiophene $/ \mathrm{Pd}\left(\mathrm{PPh}_{3}\right)_{4} /$ toluene $/ 105^{\circ} \mathrm{C} / 2 \mathrm{~h}$; (ii) $\mathrm{NBS} / \mathrm{CHCl}_{3} / \mathrm{rt} / 16 \mathrm{~h}$; (iii) $\mathrm{Pd}(\mathrm{OAc})_{2} /$ $i-\operatorname{Pr}_{2} \mathrm{EtN} /$ toluene/reflux/4.5 h. 
yield), which results from debromination of the starting material 40, as was observed in previous homo-coupling reactions.

\subsection{Physical properties}

All synthesized oligothiophenes 1-7 showed reasonable solubilities (up to $10^{-2} \mathrm{M}$ ) in several common organic solvents, such as $\mathrm{CHCl}_{3}, \mathrm{CH}_{2} \mathrm{Cl}_{2}$, toluene, and THF. This fact has allowed their characterization by NMR, UV-visible spectroscopy, and cyclic voltammetry. The observed evolution has been fully supported by quantum-chemical calculations. In practice, we have first optimized the geometry of the molecules imposed to be planar at the density functional theory (DFT) level, using the B3LYP functional (B3LYP) ${ }^{34}$ and the $6-31 \mathrm{G}(\mathrm{d}, \mathrm{p})$ basis set. Calculations were carried out using the Gaussian 03 package. ${ }^{35}$ In all calculations, the alkyl groups were replaced by methyl groups to reduce the computational costs since the saturated parts do not affect the electronic and optical properties. Since the lowest optical transition of such oligomers is mostly described by a HOMO to LUMO transition, we have compared hereafter the calculated LUMO energy in the gas phase with the electrochemical properties and the HOMO-LUMO gap to the experimental gap, see Tables 2 and 3.

Table 2

Spectroscopic properties of cyano-oligothiophenes. Measurements made in dichloromethane solutions

\begin{tabular}{lllll}
\hline Oligothiophene & $\begin{array}{l}\lambda_{\max } \\
{[\mathrm{nm}(\mathrm{eV})]}\end{array}$ & $\begin{array}{l}\varepsilon \\
{\left[\mathrm{L} \mathrm{mol}^{-1} \mathrm{~cm}^{-1}\right]}\end{array}$ & $\begin{array}{l}E_{\text {gap }}^{\mathrm{a}} \\
{[\mathrm{eV}]}\end{array}$ & $\begin{array}{l}E_{\text {gap }} \text { (calcd) } \\
{[\mathrm{eV}]}\end{array}$ \\
\hline $\mathbf{3 a}$ & $339(3.66)$ & 11,900 & 3.15 & 3.71 \\
$\mathbf{3 b}$ & $342(3.63)$ & 13,600 & 3.11 & 3.79 \\
$\mathbf{2 a}$ & $392(3.16)$ & 16,800 & 2.53 & 3.37 \\
$\mathbf{2 b}$ & $413(3.00)$ & 30,200 & 2.37 & 3.14 \\
$\mathbf{1 a}$ & $394(3.15)$ & 23,900 & 2.79 & 3.27 \\
$\mathbf{1 b}$ & $395(3.14)$ & 27,300 & 2.76 & 3.18 \\
$\mathbf{4 a}$ & $421(2.94)$ & 29,000 & 2.56 & 2.82 \\
$\mathbf{4 b}$ & $454(2.73)$ & 36,300 & 2.40 & 2.66 \\
$\mathbf{5 a}$ & $432(2.87)$ & 21,900 & 2.45 & 2.77 \\
$\mathbf{5 b}$ & $421(2.94)$ & 26,500 & 2.55 & 2.84 \\
$\mathbf{6}$ & $459(2.70)$ & 40,700 & 2.37 & 2.64 \\
$\mathbf{7}$ & $457(2.71)$ & 40,300 & 2.32 & 2.50 \\
\hline
\end{tabular}

a Optical band gap determined from the onset of the long-wavelength absorption edge $\left(\lambda_{\text {end }}\right)$ in the solution UV-vis spectra.

Table 3

Experimental values of reduction potentials $E_{\mathrm{red} 1}\left(=\left(E \mathrm{p}_{\mathrm{c} 1}+E \mathrm{p}_{\mathrm{a} 1}\right) / 2\right)$ in V versus SCE of cyano-oligothiophenes in $\mathrm{CH}_{2} \mathrm{Cl}_{2}$ containing $0.1 \mathrm{M} \mathrm{Bu}_{4} \mathrm{NPF}_{6}$, at a scan rate of $100 \mathrm{mV} \mathrm{s}^{-1}$, and their calculated LUMO $(\mathrm{eV})$

\begin{tabular}{llll}
\hline Oligothiophene & $E_{\text {red1 }}$ & LUMO $^{\mathrm{a}}$ & LUMO (calcd) \\
\hline $\mathbf{3 a}$ & -1.27 & -3.57 & -3.24 \\
$\mathbf{3 b}$ & -0.59 & -4.25 & -3.87 \\
$\mathbf{2 a}$ & -1.29 & -3.55 & -2.99 \\
$\mathbf{2 b}$ & -0.81 & -4.03 & -3.66 \\
$\mathbf{1 a}$ & -1.63 & -3.21 & -2.44 \\
$\mathbf{1 b}$ & -1.06 & -3.78 & -3.18 \\
$\mathbf{4 a}$ & -1.43 & -3.41 & -3.03 \\
$\mathbf{4 b}$ & -0.98 & -3.86 & -3.57 \\
$\mathbf{5 a}$ & -1.05 & -3.79 & -3.20 \\
$\mathbf{5 b}$ & -0.81 & -4.03 & -3.66 \\
$\mathbf{6}$ & -1.44 & -3.39 & -2.63 \\
$\mathbf{7}$ & -1.49 & -3.34 & -2.91 \\
\hline
\end{tabular}

${ }^{\mathrm{a}} \operatorname{LUMO}(\mathrm{eV})=-4.84(\mathrm{eV})-E_{\text {red } 1 .}{ }^{42}$

2.2.1. Linear spectral properties. Absorption spectra were measured in solution for each synthesized compound 1-7 (Fig. Supplementary data $1-3$, Table 2 ). The recorded spectra generally featured one broad absorption band ( $\pi-\pi^{*}$ transition), which position was affected by the nature and structure of the different compounds. It can first be noticed that within a similar series (alkyl substituted 1a-5a, 6, and 7 and ketone substituted $\mathbf{1 b}-\mathbf{4 b}$ ), increase of the conjugated system length (number of thiophene subunits) leads to a bathochromic shift of the absorption maximum. For example, a $0.95 \mathrm{eV}$ red-shift is observed between bithiophene 3a and sexithiophene $7(1.21 \mathrm{eV}$ in theory). The increment of this red-shift in $\lambda_{\max }$ value however decreases within the series. Indeed, from bithiophene $\mathbf{3 a}$ to terthiophene 2a, a wavelength increment of $0.50 \mathrm{eV}(0.34 \mathrm{eV}$ in theory) is observed, while an increment of $0.24 \mathrm{eV}(0.18 \mathrm{eV}$ in theory $)$ is measured from quaterthiophene $\mathbf{4 a}$ to quinquethiophene $\mathbf{6}$. Such phenomenon is not surprising as it has already been observed in other conjugated organic systems, ${ }^{36}$ including oligothiophenes derivatives. $27,37-39$ In addition, it can be noted that the introduction of a ketone side chain (at positions $\alpha$ and $\omega$ ) generally leads to a bathochromic shift of the absorption maximum ( $0.16 \mathrm{eV}$ between $2 \mathrm{a}$ and 2b vs $0.23 \mathrm{eV}$ in theory and $0.21 \mathrm{eV}$ between $\mathbf{4 a}$ and $\mathbf{4 b}$ vs $0.16 \mathrm{eV}$ in theory) compared to the molecules with cyano-substituted thiophenes positioned at the extremities. Such a shift can be attributed to the effective conjugation of the peripheral carbonyl group to the oligothiophene core $\pi$ system. ${ }^{13,27,40}$ A different behavior is however observed upon addition of a ketone side chain on quaterthiophene in which the cyano groups are located in the interior of the molecule. In fact, a hypsochromic shift is observed between $\mathbf{5 a}$ and $\mathbf{5 b}(-0.07 \mathrm{eV}$ at both the theoretical and experimental levels) and the effect of the positioning of cyano groups in the molecule can also be seen from comparison of absorption maxima of quarterthiophenes $\mathbf{4 b}$ and $\mathbf{5 b}$, which shows an important hypsochromic shift $(0.21 \mathrm{eV}$ vs $0.18 \mathrm{eV}$ in theory). These observations are consistent with what has been reported previously for cyano-substituted terthiophene systems. ${ }^{16,41}$

2.2.2. Electrochemical properties. Electrochemical properties of cyano-oligothiophenes were investigated using cyclic voltammetry (Table 3). One or two reversible reduction waves were observed for all compounds and reduction potentials were found to be dependent on the oligothiophene structure (Fig. Supplementary data 4-6). First reduction wave can be attributed to the formation of anion-radical species, as has been observed previously in other oligothiophene systems. ${ }^{14}$ In addition, compounds $\mathbf{3 a , b}, \mathbf{2 a}, \mathbf{b}, \mathbf{1 b}$, $\mathbf{5 a}, \mathbf{b}, \mathbf{6}$, and $\mathbf{7}$ featured a second reduction wave. This wave was ascribed to the successive reduction of the anion-radical into its corresponding dianion. ${ }^{14}$ A second reduction wave was not observed for compounds $\mathbf{1 a}$ and $\mathbf{4 a} \mathbf{a}, \mathbf{b}$. It is certainly possible that the position of this second reduction wave is located outside of the electrochemical window available. Another observation is that the reduction potentials of oligothiophenes bearing keto-alkyl chains appear shifted to more positive values than that of compounds substituted by alkyl chains. For example, $E_{\text {red } 13 \mathbf{3 b}}=-0.59 \mathrm{~V}$ (vS SCE) compared to $E_{\text {red1 } 3 a}=-1.27 \mathrm{~V}$ (vS SCE), thus leading to a shift of $0.68 \mathrm{~V}$ at the experimental level versus $0.63 \mathrm{~V}$ in theory. Furthermore, an increase of the number of $\mathrm{CN}$ groups within a similar series (from 2 in 1a,b till 4 in $\mathbf{2 a , b}$ ) also results in a shift toward more positive values of the reduction potentials. Indeed, the reduction potentials of compounds with four $\mathrm{CN}$ groups $(\mathbf{2 a}, \mathbf{b})$ are higher than those of terthiophenes with two CN groups $(\mathbf{1 a}, \mathbf{b})\left(E_{\text {red1 }} \mathbf{2 a}>E_{\text {red1 } 1 \mathbf{a}}\right.$ and $\left.E_{\text {red } 1 \mathbf{2 b}}>E_{\text {red } 1 \mathbf{1 b}}\right)$. These behaviors are attributed to the increase in the electron affinity of oligothiophene due to the presence of strong electron-withdrawing substituents ( $\mathrm{CN}$ groups and ketofunctions), thus involving the stabilization of their LUMO energy levels. Similarly to what was observed for spectroscopic properties, the electrochemical properties are affected by the position of 3,4dicyanothiophene subunits. Indeed, quaterthiophenes with cyanosubstituted thiophene positioned in the middle of the molecule (5a,b) possess reduction potentials with higher values than quaterthiophenes in which the cyano groups are located in the border of the molecule (4a,b) $\left(E_{\text {red1 }} \mathbf{5 a}>E_{\text {red1 }} \mathbf{4 a}\right.$ and $\left.E_{\text {red1 }} \mathbf{5 b}>E_{\text {red1 } 1 \mathbf{b}}\right)$. Consequently, the electronic affinity of quaterthiophene is increased when two cyano thiophenes are next to each other, as for $\mathbf{5 a}, \mathbf{b}$. This effect is less pronounced in the case of keto-alkyl substituted 
compounds $\Delta\left(E_{\text {red } 1 \mathbf{5 b}}-E_{\text {red } 1 \mathbf{4 b}}\right)=0.17 \mathrm{~V}(0.09 \mathrm{~V}$ in theory $)$ and $\Delta$ $\left(E_{\text {red1 } 5 \mathbf{a}}-\mathrm{E}_{\text {red1 } 4 \mathbf{a}}\right)=0.38 \mathrm{~V}(0.17 \mathrm{~V}$ in theory $)$.

First reduction waves were located between $-0.59 \mathrm{~V}$ and $-1.63 \mathrm{~V}$ (vs SCE). As can be noticed, apart from bithiophene $\mathbf{3 b}$ ( $E_{\text {red1 }} \mathbf{3 b}=-0.59 \mathrm{~V}$ vs SCE), all oligothiophenes exhibited high reduction potentials (from $E_{\text {red } 1} \mathbf{1 a}=-1.63 \mathrm{~V}$ to $E_{\text {red } 1} \mathbf{2 b}=E_{\text {red1 }}$ $\mathbf{5 b}=-0.81 \mathrm{~V}$ vs SCE). These potentials are however quite far from the electrochemical window determined by Facchetti and co-workers for semiconductors demonstrating stable behavior in ambient conditions. ${ }^{11}$ Consequently, these observations should limit their use as ambient stable $n$-type semiconductors in $n$-type OFET.

\section{Conclusion}

In conclusion, a new family of soluble oligothiophenes bearing cyano groups was successfully synthesized through synthetic routes involving Stille hetero-coupling and/or homo-coupling reactions as key synthetic steps. Bithiophene derivative $\mathbf{3 4}$ is an interesting building block for the synthesis of dissymmetrical oligothiophenes due to its demonstrated specific reactivity. Electrochemical and optical measurements demonstrate that the introduction of keto-alkyl chains at the extremities of those cyanooligothiophenes reduce their LUMO energy level. In addition, the number of cyano groups and their positions in the oligothiophene skeleton affect significantly the properties of those semiconductors. Close attention was paid to the first reduction potential of all the oligothiophene derivatives synthesized and bithiophene $\mathbf{3 b}$ ( $E_{\text {red1 }}$ $\mathbf{3 b}=-0.59 \mathrm{~V}$ vs SCE) is the only derivative featuring a first reduction potential suitable for ambient conditions stability $\left(\mathrm{O}_{2} / \mathrm{H}_{2} \mathrm{O}\right)$, according to the electrochemical window determined by Facchetti and co-workers. The evolution of the electrochemical and optical properties among the various compounds has been fully rationalized by quantum-chemical calculations. Study of these compounds in OFET is currently under investigation and will be reported a posteriori.

\section{Experimental section}

\subsection{Materials and methods}

All chemicals were purchased from Aldrich or Acros and used without further purification unless stated otherwise. THF was dried by conventional method $(\mathrm{Na} /$ benzophenone distillation procedure under argon) and collected with glass syringes. LDA (1.8 M solution in THF/n-heptane/ethylbenzene), anhydrous toluene, and DMF were purchased from Aldrich. TLC: $\mathrm{SiO}_{2}$ Silica gel $60 \mathrm{~F}_{254}$ on aluminum sheet (Merck). Column chromatography: Silica gel 60 (particle size $0.063-0.200 \mathrm{~mm}$, Merck). ${ }^{1} \mathrm{H}$ NMR $(300 \mathrm{MHz})$ and ${ }^{13} \mathrm{C}$ NMR $(75 \mathrm{MHz})$ were recorded on Bruker Avance 300 at room temperature. Chemical shifts are given in parts per million and coupling constants $J$ in hertz. The residual signal of the solvent was taken as internal reference standard. EI-HRMS measurements were made on a Waters AutoSpec 6 and MALDI-ToF experiments on Waters QToF Premier. Absorption spectra were recorded on an Agilent 8453 spectrophotometer in a quartz cell (optical path of $1 \mathrm{~cm}$ ) in dichloromethane (concentration solutions of $10^{-4}$ to $10^{-5} \mathrm{M}$ were used). Cyclic voltammetry experiments were performed with a computer controlled Autolab potentiostat. Measurements were carried out at room temperature in a threeelectrode single-compartment cell $(10 \mathrm{~mL})$, at a scan rate of $100 \mathrm{mV} \mathrm{s}^{-1}$. Concentrations of $10^{-3} \mathrm{M}$ or $5.10^{-4} \mathrm{M}$ (depending of the solubility of compounds) in $\mathrm{CH}_{2} \mathrm{Cl}_{2}$ solutions containing $\mathrm{Bu}_{4} \mathrm{NPF}_{6}(0.1 \mathrm{M})$ as supporting electrolyte were prepared. Before each measurement, solutions were deaerated by 10 min nitrogen bubbling. A glassy carbon, polished by a slurry-suspension of alumina on micro-cloth and washed by Milli-Q water before each experiment, was used as a working electrode. A spiral platinum wire was employed as counter electrode and an $\mathrm{Ag} / \mathrm{AgCl} / \mathrm{KCl}$ (sat) used as reference electrode was connected to the cell solution via a salt bridge containing a $\mathrm{KCl}$-saturated aqueous solution. The $\mathrm{Ag} /$ $\mathrm{AgCl}$ electrode was checked against the ferrocene/ferrocinium $\left(\mathrm{F}_{\mathrm{c}}\right)$ $\left.\mathrm{F}_{\mathrm{C}}^{+}\right)$couple $\left(E_{\mathrm{Fc} / \mathrm{Fc}+}=0.425 \mathrm{~V}\right.$ vs $\left.\mathrm{Ag} / \mathrm{AgCl}\right)$ before and after each experiment. All potentials are reported versus saturated calomel electrode ( $\mathrm{SCE})\left(E_{\mathrm{Fc} / \mathrm{Fc}+}=0.405 \mathrm{~V}\right.$ vs $\left.\mathrm{SCE}\right)$. Melting points were observed by microscopy using a Mettler FP 82 hot stage.

\subsection{Synthetic procedures}

3,4-Dibromothiophene $(\mathbf{8}){ }^{25}$ 3,4-dicyanothiophene $(\mathbf{9}),{ }^{23-25}$ 2-octylthiophene $(\mathbf{1 4})^{26}$ and 2-octyl-5-tributylstannylthiophene (15), ${ }^{26}$ 2-octyl-3,4-dibromothiophene (16), ${ }^{28}$ 2-octanoyl-3,4-dibromothiophene (19), ${ }^{29}$ and 2,5-bis(tributylstannyl)thiophene $(\mathbf{2 3})^{27}$ were prepared according to procedures described in the literature.

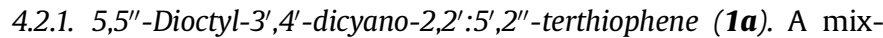
ture of 2,5-dibromo-3,4-dicyanothiophene (10) $(0.250 \mathrm{~g}, 0.86 \mathrm{mmol})$, $\mathrm{Pd}\left(\mathrm{PPh}_{3}\right)_{4}(0.150 \mathrm{~g}, 0.13 \mathrm{mmol})$, and 2-octyl-5-tributylstannylthiophene (15) $(1.455 \mathrm{~g}, 3.00 \mathrm{mmol})$ was heated at $80^{\circ} \mathrm{C}$ in dry DMF $(20 \mathrm{~mL})$ under argon during $5 \mathrm{~h}$. After cooling, a saturated solution of $\mathrm{NH}_{4} \mathrm{Cl}(40 \mathrm{~mL})$ was added and the medium was extracted with $\mathrm{CH}_{2} \mathrm{Cl}_{2}$. The organic layer was then washed with $\mathrm{H}_{2} \mathrm{O}$. After drying over $\mathrm{MgSO}_{4}$ the organic layer was concentrated under vacuum and the crude product was precipitated by addition of methanol. The dark yellow solid isolated by filtration was then purified by column on silica gel $\left(\mathrm{CH}_{2} \mathrm{Cl}_{2} /\right.$ hexane $\left.1 / 1 \mathrm{v} / \mathrm{v}\right)$. A yellow solid was obtained (0.270 g, $0.52 \mathrm{mmol}$ ). Yield: $60 \%$.

${ }^{1} \mathrm{H}$ NMR $\left(\mathrm{CDCl}_{3}\right): 7.46\left(\mathrm{~d}, 2 \mathrm{H}, J=3.75 \mathrm{~Hz}, \mathrm{H} 4, \mathrm{H} 4^{\prime \prime}\right), 6.82(\mathrm{~d}, 2 \mathrm{H}$, $\left.J=3.75 \mathrm{~Hz}, \mathrm{H} 3, \mathrm{H}^{\prime \prime}\right), 2.84\left(\mathrm{t}, 4 \mathrm{H}, J=7.54 \mathrm{~Hz},-\mathrm{CH}_{2}-\mathrm{C}_{7} \mathrm{H}_{15}\right), 1.71(\mathrm{~m}$, $\left.4 \mathrm{H},-\mathrm{CH}_{2}-\mathrm{CH}_{2}-\mathrm{C}_{6} \mathrm{H}_{13}\right), 1.34\left(\mathrm{~m}, 20 \mathrm{H},-\left(\mathrm{CH}_{2}\right)_{5}-\mathrm{CH}_{3}\right), 0.89(\mathrm{t}, 6 \mathrm{H}$, $\left.J=6.92 \mathrm{~Hz},-\mathrm{CH}_{3}\right) .{ }^{13} \mathrm{C} \mathrm{NMR}\left(\mathrm{CDCl}_{3}\right): 151.1\left(\mathrm{C} 5, \mathrm{C}^{\prime \prime}\right), 145.0\left(\mathrm{C2}^{\prime}, \mathrm{C}^{\prime}\right)$, $128.8\left(\mathrm{C} 2, \mathrm{C}^{\prime}\right), 128.6,125.8\left(\mathrm{C} 3, \mathrm{C}^{\prime \prime}, \mathrm{C} 4, \mathrm{C}^{\prime \prime}\right), 113.1\left(\mathrm{C}^{\prime}, \mathrm{C}^{\prime}\right), 105.2$ $\left(\mathrm{C}^{\prime}, \mathrm{C4}^{\prime}\right), 31.9,31.4,30.3,29.2,29.2,29.1,22.6\left(-\left(\mathrm{CH}_{2}\right)_{7}-\mathrm{CH}_{3}\right), 14.1$ $\left(\mathrm{CH}_{3}\right) . \mathrm{Mp}: 72-74^{\circ} \mathrm{C} . R_{f}\left(\mathrm{CH}_{2} \mathrm{Cl}_{2} /\right.$ hexane $\left.1 / 1 \mathrm{v} / \mathrm{v}\right)=0.65$. UV-vis $(\mathrm{nm}): \lambda_{\mathrm{abs}}=394 . \quad \mathrm{C}_{30} \mathrm{H}_{38} \mathrm{~N}_{2} \mathrm{~S}_{3}$ : EI-HRMS $\left(\mathrm{M}^{+} \bullet\right)$ : calcd: 522.2197; found: 522.2189 .

4.2.2. 5,5'-Dioctanoyl-3', $4^{\prime}$-dicyano-2,2':5', $2^{\prime \prime}$-terthiophene (1b). To a mixture of $3^{\prime}, 4^{\prime}$-dicyano-2,2':5', $2^{\prime \prime}$-terthiophene (12) $(101.5 \mathrm{mg}$, $0.34 \mathrm{mmol}$ ) and octanoyl chloride ( $165.9 \mathrm{mg}, 0.175 \mathrm{~mL}, 1.02 \mathrm{mmol}$ ) in $50 \mathrm{~mL}$ of $\mathrm{CH}_{2} \mathrm{Cl}_{2}$, was added by portions $\mathrm{AlCl}_{3}(266.7 \mathrm{mg}$, $2.00 \mathrm{mmol}$ ) at room temperature. The final mixture was stirred at reflux. After one night the starting compound was converted into 5-octanoyl-3', $4^{\prime}$-dicyano-2,2':5', $2^{\prime \prime}$-terthiophene (13) (shown by TLC). Octanoyl chloride $(1.1 \mathrm{~mL})$ and $\mathrm{AlCl}_{3}(1.0 \mathrm{~g})$ were added and the reaction mixture was refluxed during 9 days. The reaction mixture was then poured into cold $\mathrm{HCl}(6 \mathrm{M}, 50 \mathrm{~mL})$. After extraction with $\mathrm{CH}_{2} \mathrm{Cl}_{2}(3 \times 50 \mathrm{~mL})$, the combined organic layers were washed with brine $(2 \times 50 \mathrm{~mL})$ and water $(100 \mathrm{~mL})$. After drying over anhydrous $\mathrm{MgSO}_{4}$, the desired product was purified by column on silica gel $\left(\mathrm{CH}_{2} \mathrm{Cl}_{2}\right)$. A yellow solid $(103.0 \mathrm{mg}, 0.19 \mathrm{mmol})$ was obtained in $55 \%$ yield.

${ }^{1} \mathrm{H}$ NMR $\left(\mathrm{CDCl}_{3}\right): 7.72\left(\mathrm{~d}, 2 \mathrm{H}, J=4.05 \mathrm{~Hz}, \mathrm{H} 4, \mathrm{H} 4^{\prime \prime}\right), 7.70$ (d, $2 \mathrm{H}$, $\left.J=4.05 \mathrm{~Hz}, \mathrm{H} 3, \mathrm{H}^{\prime \prime}\right), 2.91\left(\mathrm{t}, 4 \mathrm{H}, J=7.39 \mathrm{~Hz},-\mathrm{CH}_{2}-\mathrm{CO}-\right), 1.76(\mathrm{~m}$, $\left.4 \mathrm{H},-\mathrm{CO}-\mathrm{CH}_{2}-\mathrm{CH}_{2}-\right), 1.35\left(\mathrm{~m}, 16 \mathrm{H},-\left(\mathrm{CH}_{2}\right)_{4}-\mathrm{CH}_{3}\right), 0.89(\mathrm{t}, 6 \mathrm{H}$, $\left.J=6.73 \mathrm{~Hz},-\mathrm{CH}_{3}\right) .{ }^{13} \mathrm{C} \mathrm{NMR}\left(\mathrm{CDCl}_{3}\right): 192.9(\mathrm{C}=\mathrm{O}), 147.1\left(\mathrm{C} 5, \mathrm{C}^{\prime \prime}\right)$, $144.7\left(\mathrm{C} 2^{\prime}, \mathrm{C}^{\prime}\right), 136.9\left(\mathrm{C} 2, \mathrm{C}^{\prime \prime}\right), 132.1,129.2\left(\mathrm{C} 3, \mathrm{C}^{\prime \prime}, \mathrm{C} 4, \mathrm{C}^{\prime \prime}\right), 112.1$ $\left(\mathrm{C}^{\prime}, \mathrm{C}^{\prime}\right), 108.7\left(\mathrm{C}^{\prime}, \mathrm{C}^{\prime}\right), 39.5\left(-\mathrm{CO}-\mathrm{CH}_{2}-\right), 31.6,29.2,29.0,24.5$, $22.6\left(-\left(\mathrm{CH}_{2}\right)_{5}-\mathrm{CH}_{3}\right), 14.1\left(-\mathrm{CH}_{3}\right) . \mathrm{Mp}: 211-212{ }^{\circ} \mathrm{C} . R_{f}\left(\mathrm{CH}_{2} \mathrm{Cl}_{2}\right)=$ 0.62. UV-vis (nm): $\lambda_{\text {abs }}=395 . \mathrm{C}_{30} \mathrm{H}_{34} \mathrm{~N}_{2} \mathrm{O}_{2} \mathrm{~S}_{3}$ : EI-HRMS $\left(\mathrm{M}^{+} \bullet\right.$ ): calcd: 550.1782; found: 550.1771 . 


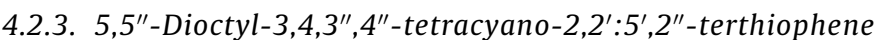
(2a). A mixture of 2,5-bis(tributylstannyl)thiophene (23) $(0.172 \mathrm{~g}$, $0.26 \mathrm{mmol}), \mathrm{Pd}\left(\mathrm{PPh}_{3}\right)_{4}(0.05 \mathrm{~g}, 0.04 \mathrm{mmol})$, and 2-bromo-5-octyl3,4-dicyanothiophène $(\mathbf{1 8})(0.166 \mathrm{~g}, 0.5 \mathrm{mmol})$ was heated overnight at $105^{\circ} \mathrm{C}$ in dry toluene $(10 \mathrm{~mL})$ under argon. After cooling, the reaction mixture was directly purified by column chromatography on silica gel $\left(\mathrm{CH}_{2} \mathrm{Cl}_{2}\right)$ to afford a yellow solid $(0.025 \mathrm{~g}$, $0.044 \mathrm{mmol})$. Yield: $17 \%$.

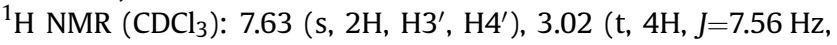
$\left.-\mathrm{CH}_{2}-\mathrm{C}_{7} \mathrm{H}_{15}\right), 1.76\left(\mathrm{~m}, 4 \mathrm{H},-\mathrm{CH}_{2}-\mathrm{CH}_{2}-\mathrm{C}_{6} \mathrm{H}_{12}\right), 1.34(\mathrm{~m}, 20 \mathrm{H}$, $\left.-\left(\mathrm{CH}_{2}\right)_{5}-\mathrm{CH}_{3}\right), 0.89\left(\mathrm{t}, 6 \mathrm{H}, \mathrm{J}=6.96 \mathrm{~Hz}, \mathrm{CH}_{3}\right) .{ }^{13} \mathrm{C} \mathrm{NMR}\left(\mathrm{CDCl}_{3}\right): 157.8$ $\left(\mathrm{C} 5, \mathrm{C}^{\prime \prime}\right), 143.4\left(\mathrm{C} 2, \mathrm{C}^{\prime \prime}\right), 134.2\left(\mathrm{C}^{\prime}, \mathrm{C}^{\prime}\right), 129.0\left(\mathrm{C}^{\prime}, \mathrm{C}^{\prime}\right), 112.6$, 111.6, 111.0, 106.5 (C3, C3" $\left., \mathrm{C4}, \mathrm{C4}{ }^{\prime \prime}, \mathrm{C} 6, \mathrm{C6}^{\prime \prime}, \mathrm{C} 7, \mathrm{C} 7^{\prime \prime}\right), 31.7,31.0,29.9$, 29.1, 29.0, $28.922 .6\left(-\left(\mathrm{CH}_{2}\right)_{7}-\mathrm{CH}_{3}\right), 14.1\left(-\mathrm{CH}_{3}\right) . \mathrm{Mp}: 194-196{ }^{\circ} \mathrm{C}$. $R_{f}\left(\mathrm{CH}_{2} \mathrm{Cl}_{2}\right)=0.70$. UV-vis $(\mathrm{nm}): \lambda_{\mathrm{abs}}=392 . \mathrm{C}_{32} \mathrm{H}_{36} \mathrm{~N}_{4} \mathrm{~S}_{3}$ : MALDIHRMS $\left(\mathrm{MNa}^{+}\right.$): calcd: 595.2000; found: 595.1989 .

4.2.4. 5,5" -Dioctanoyl-3,4,3", $4^{\prime \prime}$-tetracyano- $2,2^{\prime}: 5^{\prime}, 2^{\prime \prime}$-terthiophene (2b). A mixture of 2,5-bis(tributylstannyl)thiophene (23) (0.219 g, $0.33 \mathrm{mmol}), \mathrm{Pd}\left(\mathrm{PPh}_{3}\right)_{4}(0.110 \mathrm{~g}, 0.09 \mathrm{mmol})$, and 2-bromo-5-(2heptyl-1,3-dioxolan-2-yl)-3,4-dicyanothiophene (22) (0.253 g, $0.66 \mathrm{mmol}$ ) was heated overnight at $105^{\circ} \mathrm{C}$ in dry toluene $(10 \mathrm{~mL})$ under argon. After cooling, the mixture was directly filtrated on silica gel $\left(\mathrm{CH}_{2} \mathrm{Cl}_{2}\right)$ to afford $45 \mathrm{mg}$ of the corresponding protected terthiophene together with triphenylphospine oxide. This mixture was then solubilized in $10 \mathrm{~mL}$ of $\mathrm{CH}_{2} \mathrm{Cl}_{2}$ and $1 \mathrm{~g}$ of amberlyst ${ }^{\circledR} \mathrm{A} 15$ dry ion exchange resin was added and the mixture was stirred overnight. The resin was removed by filtration and washed with $30 \mathrm{~mL}$ of $\mathrm{CH}_{2} \mathrm{Cl}_{2}$. The filtrate was evaporated to dryness and the solid residue was dispersed in methanol, filtered, washed with methanol, and dried to afford an orange solid (16 mg, $0.03 \mathrm{mmol}$ ). Yield: $10 \%$.

${ }^{1} \mathrm{H} \mathrm{NMR}\left(\mathrm{CDCl}_{3}\right)$ : $7.85\left(\mathrm{~s}, 2 \mathrm{H}, \mathrm{H}^{\prime}, \mathrm{H}^{\prime}\right), 3.11(\mathrm{t}, 4 \mathrm{H}, J=7.21 \mathrm{~Hz}$, $\left.-\mathrm{CO}-\mathrm{CH}_{2}-\right), 1.79\left(\mathrm{~m}, 4 \mathrm{H},-\mathrm{CO}-\mathrm{CH}_{2}-\mathrm{CH}_{2}-\right), 1.32(\mathrm{~m}, 16 \mathrm{H}$, $\left.-\left(\mathrm{CH}_{2}\right)_{4}-\mathrm{CH}_{3}\right), 0.89\left(\mathrm{t}, 6 \mathrm{H}, J=6.85 \mathrm{~Hz},-\mathrm{CH}_{3}\right) .{ }^{13} \mathrm{C}$ NMR $\left(\mathrm{CDCl}_{3}\right)$ : $190.1(\mathrm{C}=\mathrm{O}), 149.5$ (C5, C5" $), 148.6\left(\mathrm{C} 2, \mathrm{C2}^{\prime \prime}\right), 134.9\left(\mathrm{C2}^{\prime}, \mathrm{C}^{\prime}\right), 130.9$

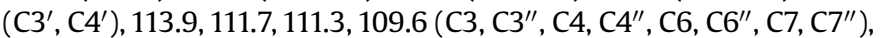
$40.7\left(-\mathrm{CO}-\mathrm{CH}_{2}-\right), 31.6,29.0,28.9,23.9,22.6\left(-\left(\mathrm{CH}_{2}\right)_{5}-\mathrm{CH}_{3}\right), 14.1$ $\left(-\mathrm{CH}_{3}\right) . \mathrm{Mp}: 224-226{ }^{\circ} \mathrm{C}$. UV-vis (nm): $\lambda_{\mathrm{abs}}=413 . \mathrm{C}_{32} \mathrm{H}_{32} \mathrm{~N}_{4} \mathrm{O}_{2} \mathrm{~S}_{3}$ : MALDI-HRMS ( $\mathrm{MNa}^{+}$): calcd: 623.1585; found: 623.1609.

4.2.5. 5,5'-Dioctyl-3,3',4,4'-tetracyano-2,2'-bithiophene (3a). A mixture of 2-bromo-5-octyl-3,4-dicyanothiophene (18) $(361.0 \mathrm{mg}$, $1.11 \mathrm{mmol}), \mathrm{Pd}(\mathrm{OAc})_{2}$ (70 mg, $0.31 \mathrm{mmol}$ ), and $i-\operatorname{Pr}_{2} \mathrm{EtN}(143.4 \mathrm{mg}$, $190 \mu \mathrm{L}, 1.11 \mathrm{mmol})$ in toluene $(15 \mathrm{~mL})$ was refluxed under argon for $2 \mathrm{~h}$. After cooling to room temperature, the mixture was purified by column chromatography on silica gel $\left(\mathrm{CH}_{2} \mathrm{Cl}_{2}\right)$ to give a white solid (150 mg, $0.31 \mathrm{mmol}$ ). Yield: $56 \%$.

${ }^{1} \mathrm{H}$ NMR $\left(\mathrm{CDCl}_{3}\right): 3.07\left(\mathrm{t}, 4 \mathrm{H}, J=7.59 \mathrm{~Hz},-\mathrm{CH}_{2}-\mathrm{C}_{7} \mathrm{H}_{15}\right), 1.79(\mathrm{~m}$, $\left.4 \mathrm{H},-\mathrm{CH}_{2}-\mathrm{CH}_{2}-\mathrm{C}_{6} \mathrm{H}_{12}\right), 1.29\left(\mathrm{~m}, 2 \mathrm{H},-\left(\mathrm{CH}_{2}\right)_{5}-\mathrm{CH}_{3}, 0.89(\mathrm{t}, 6 \mathrm{H}\right.$, $\left.J=6.95 \mathrm{~Hz}, \mathrm{CH}_{3}\right) \cdot{ }^{13} \mathrm{C} \mathrm{NMR}\left(\mathrm{CDCl}_{3}\right): 160.4\left(\mathrm{C}, \mathrm{C}^{\prime}\right), 138.0\left(\mathrm{C}^{\prime}, \mathrm{C}^{\prime}\right)$, 111.7, 111.4, 111.1, 110.7 (C3, C3', C4, C4', C6, C6', C7, C7'), 31.7, 31.0, 30.0, 29.0, 29.0, 28.9, $\left.22.6\left(\mathrm{CH}_{2}\right)_{7}-\mathrm{CH}_{3}\right), 14.0\left(\mathrm{CH}_{3}\right) . \mathrm{Mp}: 74-76{ }^{\circ} \mathrm{C} . R_{f}$ $\left(\mathrm{CH}_{2} \mathrm{Cl}_{2}\right)=0.82$. UV-vis (nm): $\lambda_{\mathrm{abs}}=339 . \mathrm{C}_{28} \mathrm{H}_{34} \mathrm{~N}_{4} \mathrm{~S}_{2}$ : EI-HRMS $\left(\mathrm{MNa}^{+}\right)$: calcd: 513.2123; found: 513.2100.

4.2.6. 5,5'-Bis(octanoyl)-3,3',4,4'-tetracyano-2,2'-bithiophene (3b). 5'-Bis(heptyl-1,3-dioxolan-2-yl)-3,3',4,4'-tétracyano-2,2'-bithiophene (28) (60 mg, $0.099 \mathrm{mmol}$ ) was dissolved in $10 \mathrm{~mL}$ of $\mathrm{CH}_{2} \mathrm{Cl}_{2}$. Then $1 \mathrm{~g}$ of amberlyst ${ }^{\circledR}$ A15 dry ion exchange resin was added and the mixture was stirred overnight. The resin was removed by filtration and washed with $20 \mathrm{~mL}$ of $\mathrm{CH}_{2} \mathrm{Cl}_{2}$. The filtrate was concentrated and then purified by column chromatography on silica gel $\left(\mathrm{CH}_{2} \mathrm{Cl}_{2}\right)$ to afford a white solid ( $\left.45 \mathrm{mg}, 0.077 \mathrm{mmol}\right)$. Yield: $88 \%$.

${ }^{1} \mathrm{H} \mathrm{NMR}\left(\mathrm{CDCl}_{3}\right): 3.13\left(\mathrm{t}, 4 \mathrm{H}, J=7.14 \mathrm{~Hz},-\mathrm{CO}-\mathrm{CH}_{2}-\right), 1.81(\mathrm{~m}, 4 \mathrm{H}$, $\left.-\mathrm{CO}-\mathrm{CH}_{2}-\mathrm{CH}_{2}-\right), 1.35\left(\mathrm{~m}, 16 \mathrm{H},-\left(\mathrm{CH}_{2}\right)_{4}-\mathrm{CH}_{3}\right), 0.89(\mathrm{t}, 6 \mathrm{H}, \mathrm{J}=6.93 \mathrm{~Hz}$, $\left.-\mathrm{CH}_{3}\right) .{ }^{13} \mathrm{C} \mathrm{NMR}\left(\mathrm{CDCl}_{3}\right)$ : $189.6(\mathrm{C}=\mathrm{O}), 153.0\left(\mathrm{C} 5, \mathrm{C}^{\prime}\right), 142.2\left(\mathrm{C} 2, \mathrm{C}^{\prime}\right)$,
115.0, 114.0, 110.7, 110.5 (C3, C3' $\left.{ }^{\prime}, \mathrm{C} 4, \mathrm{C}^{\prime}, \mathrm{C} 6, \mathrm{C}^{\prime}, \mathrm{C} 7, \mathrm{C} 7^{\prime}\right), 40.9$ (-CO-CH $2-), 31.5,29.0,28.8,23.7,22.6\left(-\left(\mathrm{CH}_{2}\right)_{5}-\mathrm{CH}_{3}\right), 14.0\left(-\mathrm{CH}_{3}\right)$. Mp: $\quad 216-218{ }^{\circ} \mathrm{C} . \quad R_{f} \quad\left(\mathrm{CH}_{2} \mathrm{Cl}_{2}\right)=0.70 . \quad \mathrm{UV}-\mathrm{vis} \quad(\mathrm{nm}): \lambda_{\mathrm{abs}}=342$. $\mathrm{C}_{28} \mathrm{H}_{30} \mathrm{~N}_{4} \mathrm{O}_{2} \mathrm{~S}_{2}$ : EI-HRMS $\left(\mathrm{M}^{+} \bullet\right.$ ): calcd: 518.1810; found: 518.1808 .

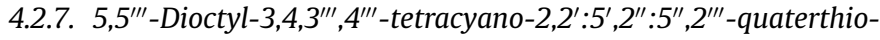
phene (4a). A mixture of bithiophene 29 ( $375.0 \mathrm{mg}, 0.92 \mathrm{mmol}$ ), Pd $(\mathrm{OAc})_{2}(94.8 \mathrm{mg}, 0.42 \mathrm{mmol})$, and $i-\operatorname{Pr}_{2} \mathrm{EtN}$ (119.0, $158 \mu \mathrm{L}$, $0.92 \mathrm{mmol})$ in toluene $(20 \mathrm{~mL})$ was refluxed under argon for $4.5 \mathrm{~h}$. After cooling to room temperature, the solvent was evaporated in vacuo. The residue was then dissolved in dichloromethane and purified by chromatography on silica gel $\left(\mathrm{CH}_{2} \mathrm{Cl}_{2}\right)$ to give an orange solid (153 mg, $0.23 \mathrm{mmol}$ ). Yield: $51 \%$.

${ }^{1} \mathrm{H} \mathrm{NMR}_{\left(\mathrm{CDCl}_{3}\right):} 7.54$ (d, $\left.2 \mathrm{H}, J=3.97 \mathrm{~Hz}, \mathrm{H}^{\prime}, \mathrm{H}^{\prime \prime}\right), 7.27$ (d, 2H, $\left.J=3.97 \mathrm{~Hz}, \mathrm{H}^{\prime}, \mathrm{H}^{\prime \prime}\right), 3.00\left(\mathrm{t}, 4 \mathrm{H}, J=7.54 \mathrm{~Hz},-\mathrm{CH}_{2}-\mathrm{C}_{7} \mathrm{H}_{15}\right), 1.76(\mathrm{~m}$, $\left.4 \mathrm{H},-\mathrm{CH}_{2}-\mathrm{CH}_{2}-\mathrm{C}_{6} \mathrm{H}_{12}\right), 1.30\left(\mathrm{~m}, 20 \mathrm{H},-\left(\mathrm{CH}_{2}\right)_{5}-\mathrm{CH}_{3}, 0.90(\mathrm{t}, 6 \mathrm{H}\right.$, $\left.\mathrm{J}=6.97 \mathrm{~Hz}, \mathrm{CH}_{3}\right) .{ }^{13} \mathrm{C} \mathrm{NMR}\left(\mathrm{CDCl}_{3}\right): 156.7\left(\mathrm{C} 5, \mathrm{C}^{\prime \prime \prime}\right), 144.6\left(\mathrm{C} 2, \mathrm{C}^{\prime \prime \prime}\right)$, $138.9\left(\mathrm{C}^{\prime}, \mathrm{C}^{\prime \prime}\right), 131.5\left(\mathrm{C}^{\prime}, \mathrm{C} 2^{\prime \prime}\right), 129.2,125.9\left(\mathrm{C}^{\prime}, \mathrm{C}^{\prime \prime}, \mathrm{C}^{\prime}, \mathrm{C} 4^{\prime \prime}\right)$, 112.9, 111.8, 110.7, 105.1 (C3, C3"', C4, C4"' C6, C6"' $\left., \mathrm{C} 7, \mathrm{C}^{\prime \prime \prime}\right), 31.7$, 31.0, 29.8, 29.1, 29.1, 28.9, $\left.22.6\left(\mathrm{CH}_{2}\right)_{7}-\mathrm{CH}_{3}\right), 14.1\left(\mathrm{CH}_{3}\right)$. Mp: $202{ }^{\circ} \mathrm{C}$. $R_{f}\left(\mathrm{CH}_{2} \mathrm{Cl}_{2}\right)=0.71$. UV-vis (nm): $\lambda_{\text {abs }}=421 . \mathrm{C}_{36} \mathrm{H}_{38} \mathrm{~N}_{4} \mathrm{~S}_{4}$ : MALDIHRMS $\left(\mathrm{M}^{+} \bullet\right)$ : calcd: 654.1979; found: 654.1965.

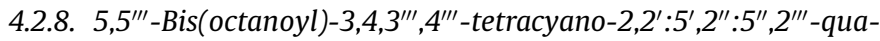
terthiophene(4b). Quaterthiophene $25(30.0 \mathrm{mg}, 0.039 \mathrm{mmol})$ was dissolved in $10 \mathrm{~mL}$ of $\mathrm{CH}_{2} \mathrm{Cl}_{2}$. Then $1.0 \mathrm{~g}$ of amberlyst ${ }^{\circledR} \mathrm{A} 15$ dry ion exchange resin was added and the mixture was stirred overnight. The resin was removed by filtration and washed with $30 \mathrm{~mL}$ of $\mathrm{CH}_{2} \mathrm{Cl}_{2}$. The filtrate was concentrated and then purified by column chromatography on silica gel $\left(\mathrm{CH}_{2} \mathrm{Cl}_{2}\right)$ to afford a red solid $(22 \mathrm{mg}$, $0.032 \mathrm{mmol}$ ). Yield: $81 \%$.

${ }^{1} \mathrm{H} \mathrm{NMR}\left(\mathrm{CDCl}_{3}\right): 7.75$ (d, 2H, $\left.J=4.07 \mathrm{~Hz}, \mathrm{H3}^{\prime}, \mathrm{H}^{\prime \prime}\right), 7.38$ (d, 2H, $\left.J=4.07 \mathrm{~Hz}, \mathrm{H3}^{\prime \prime}, \mathrm{H}^{\prime}\right), 3.1\left(\mathrm{t}, 4 \mathrm{H}, J=7.13 \mathrm{~Hz}, \mathrm{CO}-\mathrm{CH}_{2}-\right), 1.78(\mathrm{~m}, 4 \mathrm{H}$, $\left.-\mathrm{CO}-\mathrm{CH}_{2}-\mathrm{CH}_{2}-\right), 1.35\left(\mathrm{~m}, 16 \mathrm{H},-\left(\mathrm{CH}_{2}\right)_{4}-\mathrm{CH}_{3}\right), 0.90(\mathrm{t}, 6 \mathrm{H}$, $\left.J=7.01 \mathrm{~Hz},-\mathrm{CH}_{3}\right) \cdot{ }^{13} \mathrm{C}$ NMR $\left(\mathrm{CDCl}_{3}\right)$ : solubility is too low for ${ }^{13} \mathrm{C}$ NMR measurements. Mp: $274-278^{\circ} \mathrm{C} . R_{f}\left(\mathrm{CH}_{2} \mathrm{Cl}_{2}\right)=0.42$. UV-vis $(\mathrm{nm}): \lambda_{\mathrm{abs}}=454$.

4.2.9. 5, $5^{\prime \prime \prime}$-Dioctyl- $3^{\prime}, 4^{\prime}, 3^{\prime \prime}, 4^{\prime \prime}$-tetracyano- $2,2^{\prime}: 5^{\prime}, 2^{\prime \prime}: 5^{\prime \prime}, 2^{\prime \prime \prime}$-quaterthiophene (5a). A mixture of 5-bromo-5'-octyl-3,4-dicyano-2,2'bithiophene (33) (75.0 mg, $0.18 \mathrm{mmol}), \quad \mathrm{Pd}(\mathrm{OAc})_{2} \quad(20 \mathrm{mg}$, $0.09 \mathrm{mmol})$, and $i-\operatorname{Pr}_{2} \mathrm{EtN}(24.0 \mathrm{mg}, 32 \mu \mathrm{L}, 0.18 \mathrm{mmol})$ in toluene $7 \mathrm{~mL}$ under argon was refluxed for $1.5 \mathrm{~h}$. After cooling to room temperature, the mixture was directly purified by column chromatography on silica gel $\left(\mathrm{CH}_{2} \mathrm{Cl}_{2}\right)$ to afford the desired quaterthiophene 5a as an orange solid (36.0 mg, $0.06 \mathrm{mmol}$ ). Yield: $60 \%$.

${ }^{1} \mathrm{H} \mathrm{NMR}\left(\mathrm{CDCl}_{3}\right): 7.60$ (d, $\left.2 \mathrm{H}, J=3.79 \mathrm{~Hz}, \mathrm{H} 3, \mathrm{H3}^{\prime \prime \prime}\right), 6.88(\mathrm{~d}, 2 \mathrm{H}$, $\left.J=3.79 \mathrm{~Hz}, \mathrm{H} 4, \mathrm{H}^{\prime \prime \prime}\right), 2.88\left(\mathrm{t}, 4 \mathrm{H}, J=7.51 \mathrm{~Hz},-\mathrm{CH}_{2}-\mathrm{C}_{7} \mathrm{H}_{15}\right), 1.73(\mathrm{~m}$, $\left.4 \mathrm{H},-\mathrm{CH}_{2}-\mathrm{CH}_{2}-\mathrm{C}_{6} \mathrm{H}_{13}\right), 1.35\left(\mathrm{~m}, 20 \mathrm{H},-\left(\mathrm{CH}_{2}\right)_{5}-\mathrm{CH}_{3}\right), 0.89(\mathrm{t}, 6 \mathrm{H}$, $\left.J=6.93 \mathrm{~Hz}, \mathrm{CH}_{3}\right) .{ }^{13} \mathrm{C} \mathrm{NMR}\left(\mathrm{CDCl}_{3}\right): 153.5\left(\mathrm{C} 5, \mathrm{C}^{\prime \prime \prime}\right), 149.4\left(\mathrm{C} 2, \mathrm{C}^{\prime \prime \prime}\right)$, $135.9\left(\mathrm{C}^{\prime}, \mathrm{C}^{\prime \prime}\right), 130.3\left(\mathrm{C} 4, \mathrm{C} 4^{\prime \prime \prime}\right), 127.6\left(\mathrm{C}^{\prime}, \mathrm{C}^{\prime \prime}\right), 126.4\left(\mathrm{C} 3, \mathrm{C}^{\prime \prime \prime}\right)$, 112.3, 112.0, 111.8, 105.8 (C3', C4', C6', C7', C3", C4", C6" $\left.{ }^{\prime \prime}, \mathrm{C}^{\prime \prime}\right), 31.8$, 31.4, 30.4, 29.2, 29.1, 29.0, $22.6\left(-\left(\mathrm{CH}_{2}\right)_{7}-\right), 14.1\left(\mathrm{CH}_{3}\right) . \mathrm{Mp}$ : 201-203 ${ }^{\circ} \mathrm{C} . R_{f}\left(\mathrm{CH}_{2} \mathrm{Cl}_{2}\right)=0.88$. UV-vis $(\mathrm{nm}): \lambda_{\mathrm{abs}}=432 . \mathrm{C}_{36} \mathrm{H}_{38} \mathrm{~N}_{4} \mathrm{~S}_{4}$ : MALDI-HRMS $\left(\mathrm{M}^{+} \bullet\right.$ ): calcd: 654.1979; found: 654.1968 .

4.2.10. 5,5'"-Dioctanoyl-3', $4^{\prime}, 3^{\prime \prime}, 4^{\prime \prime}$-tetracyano- $2,2^{\prime}: 5^{\prime}, 2^{\prime \prime}: 5^{\prime \prime}, 2^{\prime \prime \prime}$-quaterthiophene (5b). A mixture of 5-bromo-5'-octanoyl-3,4-dicyano2,2'-bithiophene (37) $(83.0 \mathrm{mg}, 0.20 \mathrm{mmol}), \mathrm{Pd}(\mathrm{OAc})_{2}(20 \mathrm{mg}$, $0.09 \mathrm{mmol})$, and $i-\operatorname{Pr}_{2} \operatorname{EtN}(25.9 \mathrm{mg}, 34 \mu \mathrm{L}, 0.20 \mathrm{mmol})$ in toluene $(6 \mathrm{~mL})$ was refluxed under argon for $1.5 \mathrm{~h}$. After cooling to room temperature, the mixture was directly purified on column chromatography on silica gel $\left(\mathrm{CH}_{2} \mathrm{Cl}_{2}\right)$ to afford the desired quaterthiophene as an orange solid $(36.0 \mathrm{mg}, 0.05 \mathrm{mmol})$. Yield: $53 \%$.

${ }^{1} \mathrm{H} \mathrm{NMR}\left(\mathrm{CDCl}_{3}\right): 7.78$ (d, $\left.2 \mathrm{H}, J=4.06 \mathrm{~Hz}, \mathrm{H} 4, \mathrm{H}^{\prime \prime \prime}\right), 7.73$ (d, 2H, $J=4.06 \mathrm{~Hz}, \mathrm{H} 3, \mathrm{H3}^{\prime \prime \prime}$ ), 2.93 (t, 4H, $\left.J=7.31 \mathrm{~Hz},-\mathrm{CH}_{2}-\mathrm{CO}-\right), 1.77$ (m, 
$\left.4 \mathrm{H},-\mathrm{CO}-\mathrm{CH}_{2}-\mathrm{CH}_{2}-\right), 1.34\left(\mathrm{~m}, 16 \mathrm{H},-\left(\mathrm{CH}_{2}\right)_{4}-\mathrm{CH}_{3}, 0.89(\mathrm{t}, 6 \mathrm{H}\right.$, $\left.J=6.85 \mathrm{~Hz}, \mathrm{CH}_{3}\right) .{ }^{13} \mathrm{C}$ NMR $\left(\mathrm{CDCl}_{3}\right): 192.7(\mathrm{C}=\mathrm{O}), 148.2\left(\mathrm{C} 5, \mathrm{C}^{\prime \prime \prime}\right)$, 147.9 (C2, C2'"') , 137.4, 135.7 (C2', C5", C5', C2" ), 132.0, 130.3 (C3, $\left.\mathrm{C}^{\prime \prime \prime}, \mathrm{C} 4, \mathrm{C}^{\prime \prime \prime}\right), 113.2,111.5,111.2,109.00\left(\mathrm{C}^{\prime}, \mathrm{C}^{\prime \prime}, \mathrm{C}^{\prime}, \mathrm{C}^{\prime \prime} \mathrm{C}^{\prime}, \mathrm{C}^{\prime \prime}\right.$, $\left.\left.\mathrm{C}^{\prime}, \mathrm{C}^{\prime \prime}\right), 39.6\left(-\mathrm{CO}-\mathrm{CH}_{2}-\right), 31.6,29.2,29.0,24.4,22.6\left(\mathrm{CH}_{2}\right)_{5}-\mathrm{CH}_{3}\right)$, $14.1 \quad\left(\mathrm{CH}_{3}\right) . \quad \mathrm{Mp}: \quad 214^{\circ} \mathrm{C} . \quad R_{f} \quad\left(\mathrm{CH}_{2} \mathrm{Cl}_{2}\right)=0.45$. UV-vis $(\mathrm{nm})$ : $\lambda_{\mathrm{abs}}=421 \mathrm{~nm}$.

4.2.11. 5, 5"'"-Dioctyl- $3^{\prime \prime}, 4^{\prime \prime}$-dicyano- $2,2^{\prime}: 5^{\prime}, 2^{\prime \prime}: 5^{\prime \prime}, 2^{\prime \prime \prime}: 5^{\prime \prime \prime}, 2^{\prime \prime \prime \prime}$-quinquethiophene (6). A mixture of $5,5^{\prime \prime}$-dibromo- $3^{\prime}, 4^{\prime}$-dicyano- $2,2^{\prime}: 5^{\prime}, 2^{\prime \prime}-$ terthiophene (38) $(0.128 \mathrm{~g}, 0.28 \mathrm{mmol}), \quad \mathrm{Pd}\left(\mathrm{PPh}_{3}\right)_{4} \quad(0.060 \mathrm{~g}$, $0.005 \mathrm{mmol})$, and 2-octyl-5-tributylstannylthiophene (15) (0.477 g, $0.98 \mathrm{mmol}$ ) was heated at $80{ }^{\circ} \mathrm{C}$ in dry DMF $(20 \mathrm{~mL})$ under argon during $4.5 \mathrm{~h}$. After cooling, a saturated solution of $\mathrm{NH}_{4} \mathrm{Cl}(30 \mathrm{~mL})$ was added and the medium extracted with $\mathrm{CH}_{2} \mathrm{Cl}_{2}$. The organic layer was then washed with $\mathrm{H}_{2} \mathrm{O}$. After drying over $\mathrm{MgSO}_{4}$ the organic layer was concentrated under vacuum and the crude product was precipitated by addition of methanol. The dark red solid isolated by filtration was then purified by column chromatography on silica gel $\left(\mathrm{CH}_{2} \mathrm{Cl}_{2}\right)$ to give a red solid $(0.128 \mathrm{~g}, 0.19 \mathrm{mmol})$. Yield: $67 \%$.

${ }^{1} \mathrm{H} \mathrm{NMR}\left(\mathrm{CDCl}_{3}\right): 7.55\left(\mathrm{~d}, 2 \mathrm{H}, J=3.98 \mathrm{~Hz}, \mathrm{H}^{\prime}, \mathrm{H}^{\prime \prime \prime \prime}\right), 7.10(\mathrm{~d}, 2 \mathrm{H}$, $\left.J=3.52 \mathrm{~Hz}, \mathrm{H} 3, \mathrm{H}^{\prime \prime \prime \prime}\right), 7.09$ (d, 2H, $J=3.98 \mathrm{~Hz}, \mathrm{H}^{\prime}, \mathrm{H}^{\prime \prime \prime}$ ), 6.73 (d, 2H, $\left.J=3.52 \mathrm{~Hz}, \mathrm{H} 4, \mathrm{H} 4^{\prime \prime \prime \prime}\right), 2.81\left(\mathrm{t}, 4 \mathrm{H}, J=7.47 \mathrm{~Hz},-\mathrm{CH}_{2}-\mathrm{C}_{7} \mathrm{H}_{15}\right), 1.69(\mathrm{~m}$, $\left.4 \mathrm{H},-\mathrm{CH}_{2}-\mathrm{CH}_{2}-\mathrm{C}_{6} \mathrm{H}_{13}\right), 1.33\left(\mathrm{~m}, 2 \mathrm{H},-\left(\mathrm{CH}_{2}\right)_{5}-\mathrm{CH}_{3}\right), 0.89(\mathrm{t}, 6 \mathrm{H}$, $\left.J=6.94 \mathrm{~Hz},-\mathrm{CH}_{3}\right) \cdot{ }^{13} \mathrm{CNMR}\left(\mathrm{CDCl}_{3}\right): 147.8\left(\mathrm{C}, \mathrm{C}^{\prime \prime \prime \prime}\right), 144.1\left(\mathrm{C}^{\prime \prime}, \mathrm{C}^{\prime \prime}\right)$, $142.2\left(\mathrm{C}^{\prime}, \mathrm{C} 2^{\prime \prime \prime}\right), 132.9\left(\mathrm{C}^{\prime}, \mathrm{C} 5^{\prime \prime \prime}\right), 129.4\left(\mathrm{C}^{\prime}, \mathrm{C}^{\prime \prime \prime}\right), 128.7\left(\mathrm{C} 2, \mathrm{C}^{\prime \prime \prime \prime}\right)$, 125.3, $125.2\left(\mathrm{C} 3, \mathrm{C}^{\prime}, \mathrm{C}^{\prime \prime \prime \prime}, \mathrm{C} 4^{\prime \prime \prime}\right), 123.8\left(\mathrm{C} 4, \mathrm{C}^{\prime \prime \prime \prime}\right), 113.0\left(\mathrm{C}^{\prime \prime}, \mathrm{C} 7^{\prime \prime}\right)$, 105.5 (C3", $\left.\mathrm{C4}^{\prime \prime}\right), 31.8,31.5,30.2,29.3,29.2,29.1,22.3\left(-\left(\mathrm{CH}_{2}\right)_{7}-\right), 14.1$ $\left(\mathrm{CH}_{3}\right)$. Mp: $146-148^{\circ} \mathrm{C} . R_{f}\left(\mathrm{CH}_{2} \mathrm{Cl}_{2}\right)=0.93$. UV-vis $(\mathrm{nm}): \lambda_{\mathrm{abs}}=459$. $\mathrm{C}_{38} \mathrm{H}_{42} \mathrm{~N}_{2} \mathrm{~S}_{5}$ : MALDI-HRMS ( $\mathrm{M}^{+} \bullet$ ): calcd: 686.1952; found: 686.1973 .


$5^{\prime \prime \prime \prime}, 2^{\prime \prime \prime \prime \prime}$-sexithiophene (7). A mixture of 5-octyl-5"'-bromo-3,4-

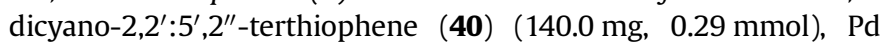
$(\mathrm{OAc})_{2}(45 \mathrm{mg}, 0.20 \mathrm{mmol})$, and $i-\operatorname{Pr}_{2} \operatorname{EtN}(37.5 \mathrm{mg}, 50 \mu \mathrm{L}, 0.29 \mathrm{mmol})$ in toluene $(8 \mathrm{~mL})$ was refluxed under argon for $4.5 \mathrm{~h}$. After cooling to room temperature, the mixture was directly purified on column chromatography on silica gel $\left(\mathrm{CH}_{2} \mathrm{Cl}_{2}\right)$ to afford the desired sexithiophene as a red solid (13.0 $\mathrm{mg}, 0.016 \mathrm{mmol})$. Yield: $11 \%$.

${ }^{1} \mathrm{H} \mathrm{NMR}\left(\mathrm{CDCl}_{3}\right): 7.53\left(\mathrm{~d}, 2 \mathrm{H}, \mathrm{J}=3.96 \mathrm{~Hz}, \mathrm{H} 3^{\prime}, \mathrm{H}^{\prime \prime \prime \prime}\right), 7.19(\mathrm{~m}, 4 \mathrm{H}$, $\mathrm{H}^{\prime \prime}, \mathrm{H}^{\prime \prime \prime \prime \prime}, \mathrm{H} 4^{\prime}, \mathrm{H} 4^{\prime \prime \prime}$ ), 7.14 (d, 2H, J=3.82 Hz, H3 ${ }^{\prime \prime \prime}, \mathrm{H} 4^{\prime \prime}$ ), 2.99 (t, 4H, $\left.J=7.54 \mathrm{~Hz},-\mathrm{CH}_{2}-\mathrm{C}_{7} \mathrm{H}_{15}\right), 1.75\left(\mathrm{~m}, 4 \mathrm{H},-\mathrm{CH}_{2}-\mathrm{CH}_{2}-\mathrm{C}_{6} \mathrm{H}_{13}\right), 1.34(\mathrm{~m}$, $\left.2 \mathrm{OH},-\left(\mathrm{CH}_{2}\right)_{5}-\mathrm{CH}_{3}\right), 0.89\left(\mathrm{t}, 6 \mathrm{H}, J=6.94 \mathrm{~Hz},-\mathrm{CH}_{3}\right) .{ }^{13} \mathrm{C} \mathrm{NMR}\left(\mathrm{CDCl}_{3}\right)$ : solubility is too low for ${ }^{13} \mathrm{C}$ NMR measurements. Mp: $208{ }^{\circ} \mathrm{C}$. UV-vis (nm): $\lambda_{\text {abs }}=457 . \mathrm{C}_{44} \mathrm{H}_{42} \mathrm{~N}_{4} \mathrm{~S}_{6}$ : MALDI-HRMS $\left(\mathrm{M}^{+} \bullet\right.$ ): calcd: 818.1734; found: 818.1740 .

4.2.13. 2,5-Dibromo-3,4-dicyanothiophene (10). A solution of 3,4dicyanothiophene $(\mathbf{9})(2.19 \mathrm{~g}, 7.9 \mathrm{mmol})$ in dry THF $(120 \mathrm{~mL})$ under argon, was cooled to $-80^{\circ} \mathrm{C}$ and $27.2 \mathrm{~mL}(49.0 \mathrm{mmol})$ of LDA (1.8 M in solution in THF/n-heptane/ethylbenzene) was added dropwise. After stirring this mixture for $15 \mathrm{~min}$ at $-80^{\circ} \mathrm{C}$, bromine $(1.88 \mathrm{~mL}$, $36.0 \mathrm{mmol}$ ) was slowly added. The mixture was then stirred for $2 \mathrm{~h}$ at $-80^{\circ} \mathrm{C} /-50^{\circ} \mathrm{C}$. The reaction was then quenched by adding $50 \mathrm{~mL}$ of a saturated aqueous solution of $\mathrm{NH}_{4} \mathrm{Cl}$. The mixture was extracted with $\mathrm{CH}_{2} \mathrm{Cl}_{2}$ and the organic layer was dried over magnesium sulfate and then evaporated to dryness. The crude solid produced was then purified by chromatography on silica gel $\left(\mathrm{CH}_{2} \mathrm{Cl}_{2}\right)$ to give 2,5-dibromo-3,4-dicyanothiophene (10) (2.95 g, $10.1 \mathrm{mmol}$ ) as a white solid. Yield: $62 \%$.

${ }^{13}$ C NMR (DMSO-d $\left.d_{6}\right): 126.4$ (C2, C5), 114.4 (C3, C4), 111.3 (C6, C7). Mp: $194-195^{\circ} \mathrm{C} . R_{f}\left(\mathrm{CH}_{2} \mathrm{Cl}_{2}\right)=0.72 . \mathrm{C}_{6} \mathrm{Br}(79)_{2} \mathrm{~N}_{2} \mathrm{~S}$ : EI-HRMS $\left(\mathrm{M}^{+} \bullet\right)$ : calcd: 289.8153 ; found: 289.8149 .

4.2.14. 2,5-Bis(tributylstannyl)-3,4-dicyanothiophene (11). A solution of 3,4-dicyanothiophene (9) $(406.0 \mathrm{mg}, 3.03 \mathrm{mmol})$ in dry THF
$(50 \mathrm{~mL})$ under argon, was cooled to $-80^{\circ} \mathrm{C}$ and $5.05 \mathrm{~mL}$ ( $9.09 \mathrm{mmol})$ of LDA (1.8 M in solution in THF/n-heptane/ethylbenzene) was slowly added ( $10 \mathrm{~min}$ ). The mixture was then stirred for $10 \mathrm{~min}$ at $-80^{\circ} \mathrm{C}$ and $1.81 \mathrm{~mL}$ of tributyltin chloride $(2.17 \mathrm{~g}$, $6.66 \mathrm{mmol}$ ) was added in $10 \mathrm{~min}$. The medium was stirred for $1 \mathrm{~h}$ at $-80^{\circ} \mathrm{C}$. The reaction was then quenched by adding $40 \mathrm{~mL}$ of a saturated aqueous solution of $\mathrm{NH}_{4} \mathrm{Cl}(40 \mathrm{~mL})$. The mixture was extracted with $\mathrm{CH}_{2} \mathrm{Cl}_{2}$. The combined organic layers were dried over $\mathrm{MgSO}_{4}$ and concentrated. The product was purified by chromatography on silica gel $\left(\mathrm{CH}_{2} \mathrm{Cl}_{2} /\right.$ hexane $\left.6 / 4 \mathrm{v} / \mathrm{v}\right)$ to give $1.71 \mathrm{~g}$ (2.40 mmol, $79 \%$.) of colorless oil.

${ }^{1} \mathrm{H}$ NMR $\left(\mathrm{CDCl}_{3}\right): 1.56\left(\mathrm{~m}, 12 \mathrm{H}, \mathrm{CH}_{2}-\left(\mathrm{CH}_{2}\right)_{2}-\mathrm{CH}_{3}\right), 1.33(\mathrm{~m}, 24 \mathrm{H}$, $\left.\mathrm{CH}_{2}-\left(\mathrm{CH}_{2}\right)_{2}-\mathrm{CH}_{3}\right), 0.90\left(\mathrm{t}, 18 \mathrm{H}, \mathrm{J}=6.97 \mathrm{~Hz}, \mathrm{CH}_{3}\right) .{ }^{13} \mathrm{C} \mathrm{NMR}\left(\mathrm{CDCl}_{3}\right)$ : 159.5 (C2, C5), 121.0 (C3, C4), 114.9 (C6, C7), 28.8, 27.1, 13.6 $\left(-\left(\mathrm{CH}_{2}\right)_{3}-\mathrm{CH}_{3}\right), 11.4\left(\mathrm{CH}_{3}\right) \cdot R_{f}\left(\mathrm{CH}_{2} \mathrm{Cl}_{2} /\right.$ hexane $\left.6 / 4 \mathrm{v} / \mathrm{v}\right)=0.95$.

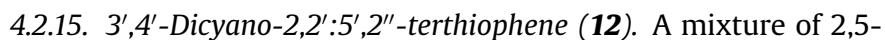
dibromo-3,4-dicyanothiophene (10) $(0.400 \mathrm{~g}, 1.37 \mathrm{mmol}), \quad \mathrm{Pd}$ $\left(\mathrm{PPh}_{3}\right)_{4}(0.061 \mathrm{~g}, 0.053 \mathrm{mmol})$, and 2-(tributylstannyl)thiophene $(1.023 \mathrm{~g}, 0.871 \mathrm{~mL}, 2.74 \mathrm{mmol})$ was heated at $80^{\circ} \mathrm{C}$ in dry DMF $(15 \mathrm{~mL})$ under argon during $24 \mathrm{~h}$. After cooling, a saturated solution of $\mathrm{NH}_{4} \mathrm{Cl}(40 \mathrm{~mL})$ was added and the mixture was extracted with $\mathrm{CH}_{2} \mathrm{Cl}_{2}$. The organic layer was then washed with $\mathrm{H}_{2} \mathrm{O}$. After drying over $\mathrm{MgSO}_{4}$ the organic layer was concentrated under vacuum. Purification by column on silica gel eluting by $\mathrm{CH}_{2} \mathrm{Cl}_{2}$ afforded

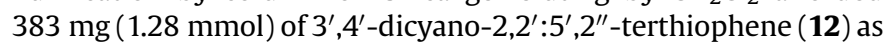
a yellow solid. Yield: $93 \%$.

${ }^{1} \mathrm{H}$ NMR $\left(\mathrm{CDCl}_{3}\right): 7.67$ (dd, $2 \mathrm{H}, J=1.06$ and $\left.3.76 \mathrm{~Hz}, \mathrm{H} 5, \mathrm{H} 5^{\prime \prime}\right), 7.53$ (dd, $2 \mathrm{H}, J=1.05$ and $5.10 \mathrm{~Hz}, \mathrm{H} 3, \mathrm{H}^{\prime \prime}$ ), 7.18 (dd, $2 \mathrm{H}, J=3.80$ and $\left.5.07 \mathrm{~Hz}, \mathrm{H} 4, \mathrm{H}^{\prime \prime}\right) .{ }^{13} \mathrm{C} \mathrm{NMR}\left(\mathrm{CDCl}_{3}\right): 145.0\left(\mathrm{C}^{\prime}, \mathrm{C}^{\prime}\right), 131.2\left(\mathrm{C} 2, \mathrm{C}^{\prime \prime}\right)$, 129.4, 128.7 (C3, C3" $\left.{ }^{\prime \prime}, \mathrm{C} 4, \mathrm{C}^{\prime \prime}, \mathrm{C} 5, \mathrm{C}^{\prime \prime}\right), 112.8\left(\mathrm{C6}^{\prime}, \mathrm{C} 7^{\prime}\right), 106.5\left(\mathrm{C}^{\prime}\right.$, $\left.\mathrm{C} 4^{\prime}\right) . \mathrm{Mp}=195-197^{\circ} \mathrm{C} . R_{f}\left(\mathrm{CH}_{2} \mathrm{Cl}_{2}\right)=0.81$. UV-vis $(\mathrm{nm}): \lambda_{\mathrm{abs}}=375$. $\mathrm{C}_{14} \mathrm{H}_{6} \mathrm{~N}_{2} \mathrm{~S}_{3}$ : EI-HRMS $\left(\mathrm{M}^{+} \bullet\right.$ ): calcd: 297.9693; found: 297.9697.

4.2.16. 5-Octanoyl-3', $4^{\prime}$-dicyano-2, $2^{\prime}: 5^{\prime}, 2^{\prime \prime}$-terthiophene (13). Prepared similarly to $\mathbf{1 b}$ starting from a mixture of $3^{\prime}, 4^{\prime}-$ dicyano-2,2': $: 5^{\prime}, 2^{\prime \prime}$-terthiophene (12) $(101.5 \mathrm{mg}, 0.34 \mathrm{mmol})$ and octanoyl chloride $\left(165.9 \mathrm{mg}, 0.175 \mathrm{~mL}, 1.02 \mathrm{mmol}\right.$ ) and $\mathrm{AlCl}_{3}$ (266.7 mg, $2.00 \mathrm{mmol}$ ). Yield: $20 \%$.

${ }^{1} \mathrm{H}$ NMR $\left(\mathrm{CDCl}_{3}\right): 7.70\left(\mathrm{~m}, 3 \mathrm{H}, \mathrm{H} 5, \mathrm{H}^{\prime \prime}, \mathrm{H} 4^{\prime \prime}\right), 7.57$ (dd, $1 \mathrm{H}, J=1.05$ and $5.09 \mathrm{~Hz}, \mathrm{H} 3), 7.19(\mathrm{dd}, 1 \mathrm{H}, J=3.82$ and $5.07 \mathrm{~Hz}, \mathrm{H} 4), 2.91(\mathrm{t}, 2 \mathrm{H}$, $\left.J=7.40 \mathrm{~Hz},-\mathrm{CH}_{2}-\mathrm{CO}-\right), 1.75\left(\mathrm{~m}, 2 \mathrm{H},-\mathrm{CO}-\mathrm{CH}_{2}-\mathrm{CH}_{2}-\right), 1.35(\mathrm{~m}, 8 \mathrm{H}$, $\left.-\left(\mathrm{CH}_{2}\right)_{4}-\mathrm{CH}_{3}\right), 0.89\left(\mathrm{t}, 3 \mathrm{H}, J=6.74 \mathrm{~Hz},-\mathrm{CH}_{3}\right) .{ }^{13} \mathrm{C} \mathrm{NMR}\left(\mathrm{CDCl}_{3}\right)$ : $192.9(\mathrm{C}=\mathrm{O}), 146.6,146.5\left(\mathrm{C} 2^{\prime}, \mathrm{C}^{\prime}\right), 143.2\left(\mathrm{C} 2^{\prime \prime}\right), 137.4\left(\mathrm{C}^{\prime \prime}\right), 132.1$ (C5), 130.9 (C2), 130.0, 129.2, 128.9, 128.7 (C3, C3" $\left., \mathrm{C} 4, \mathrm{C}^{\prime \prime}\right), 112.5$, $112.4\left(\mathrm{C6}^{\prime}, \mathrm{C}^{\prime}\right), 108.3,106.7$ (C3, C4), $39.4\left(-\mathrm{CO}-\mathrm{CH}_{2}-\right)$, 31.6, 29.2, 29.0, 24.5, $22.6\left(-\left(\mathrm{CH}_{2}\right)_{5}-\mathrm{CH}_{3}\right), 14.1\left(-\mathrm{CH}_{3}\right) . \mathrm{Mp}=132-133^{\circ} \mathrm{C} . R_{f}$ $\left(\mathrm{CH}_{2} \mathrm{Cl}_{2}\right)=0.73$. UV-vis $(\mathrm{nm}): \lambda_{\mathrm{abs}}=387 . \mathrm{C}_{22} \mathrm{H}_{20} \mathrm{~N}_{2} \mathrm{OS}_{3}$ : EI-HRMS $\left(\mathrm{M}^{+} \bullet\right.$ ): calcd: 424.0727; found: 424.0738 .

4.2.17. 2-Octyl-3,4-dicyanothiophene (17). A mixture of 2-octyl-3,4dibromothiophene (16) (10.55 g, $29.8 \mathrm{mmol})$ and $\mathrm{CuCN}(8.00 \mathrm{~g}$, $89.4 \mathrm{mmol}$ ) in dry DMF (35 mL) was stirred under reflux for $4 \mathrm{~h}$. After cooling, to the resulting dark solution was added a solution of $\mathrm{FeCl}_{3}(29.20 \mathrm{~g})$ in $2 \mathrm{M} \mathrm{HCl}(62 \mathrm{~mL})$ and the mixture was stirred at $70{ }^{\circ} \mathrm{C}$ for $1 \mathrm{~h}$. After cooling to room temperature, this mixture was extracted several times with $\mathrm{CH}_{2} \mathrm{Cl}_{2}$. The organic layers were combined and washed successively with $6 \mathrm{M} \mathrm{HCl}$ (two times), water, saturated $\mathrm{NaHCO}_{3}$ solution, and again water. The organic layer was dried over $\mathrm{MgSO}_{4}$, filtrated, and evaporated to dryness. The crude product was then purified by chromatography on silica gel $\left(\mathrm{CH}_{2} \mathrm{Cl}_{2} /\right.$ hexane $1 / 1 \mathrm{v} / \mathrm{v}$ ) to afford $4.32 \mathrm{~g}$ of a pale yellow liquid. Yield: $59 \%$.

${ }^{1} \mathrm{H} \mathrm{NMR}\left(\mathrm{CDCl}_{3}\right): 7.82(\mathrm{~s}, 1 \mathrm{H}, \mathrm{H} 5), 3.02(\mathrm{t}, 2 \mathrm{H}, J=7.57 \mathrm{~Hz}$, $\left.-\mathrm{CH}_{2}-\mathrm{C}_{7} \mathrm{H}_{15}\right), 1.74\left(\mathrm{~m}, 2 \mathrm{H},-\mathrm{CH}_{2}-\mathrm{CH}_{2}-\mathrm{C}_{6} \mathrm{H}_{12}\right), 1.30(\mathrm{~m}, 10 \mathrm{H}$, $-\left(\mathrm{CH}_{2}\right)_{5}-\mathrm{CH}_{3}, 0.88\left(\mathrm{t}, 3 \mathrm{H}, \mathrm{J}=6.97 \mathrm{~Hz}, \mathrm{CH}_{3}\right) \cdot{ }^{13} \mathrm{C} \mathrm{NMR}\left(\mathrm{CDCl}_{3}\right): 159.6$ (C2), 134.1 (C5), 112.2, 112.0, 111.8, 109.9 (C3, C4, C6, C7), 31.7, 31.1, 
29.7, 29.0 (Int. $\left.\left.=2 \mathrm{CH}_{2}\right), 28.8,22.6\left(\mathrm{CH}_{2}\right)_{7}-\mathrm{CH}_{3}\right), 14.0\left(\mathrm{CH}_{3}\right) . R_{f}$ $\left(\mathrm{CH}_{2} \mathrm{Cl}_{2} /\right.$ hexane $\left.1 / 1 \mathrm{v} / \mathrm{v}\right)=0.25 . \mathrm{C}_{14} \mathrm{H}_{18} \mathrm{~N}_{2} \mathrm{~S}$ : EI-MS: $\left(\mathrm{M}^{+} \bullet\right)=245$.

4.2.18. 2-Bromo-5-octyl-3,4-dicyanothiophene (18). A solution of 2-octyl-3,4-dicyanothiophene (17) $(3.35 \mathrm{~g}, 13.6 \mathrm{mmol})$ in dry THF $(90 \mathrm{~mL})$ was cooled under argon to $-80^{\circ} \mathrm{C}$ and $15.11 \mathrm{~mL}$ (27.2 mmol) of LDA (1.8 M in solution in THF/n-heptane/ethylbenzene) was added dropwise. The mixture was stirred for $10 \mathrm{~min}$, then $1.7 \mathrm{~mL}$ of bromine $(5.31 \mathrm{~g}, 16.32 \mathrm{mmol}$ ) was slowly added. The mixture was then allowed to warm to $-50^{\circ} \mathrm{C}$ (30 min). After adding a saturated solution of $\mathrm{NH}_{4} \mathrm{Cl}(20 \mathrm{~mL})$, the solution was extracted with $\mathrm{CH}_{2} \mathrm{Cl}_{2}$. The organic layers were dried over $\mathrm{MgSO}_{4}$, filtrated, and concentrated. The brown liquid residue was dissolved in $\mathrm{CH}_{2} \mathrm{Cl}_{2}$ and purified by chromatography on silica gel (elution with $\mathrm{CH}_{2} \mathrm{Cl}_{2} /$ hexane $1 / 1 \mathrm{v} / \mathrm{v}$ ) to give a yellow liquid $(4.23 \mathrm{~g}$, $13.0 \mathrm{mmol}$ ), which crystallized in the fridge. Yield: $96 \%$.

${ }^{1} \mathrm{H}$ NMR $\left(\mathrm{CDCl}_{3}\right): 2.98\left(\mathrm{t}, 2 \mathrm{H}, J=7.57 \mathrm{~Hz},-\mathrm{CH}_{2}-\mathrm{C}_{7} \mathrm{H}_{15}\right), 1.71(\mathrm{~m}$, $\left.2 \mathrm{H},-\mathrm{CH}_{2}-\mathrm{CH}_{2}-\mathrm{C}_{6} \mathrm{H}_{12}\right), 1.27\left(\mathrm{~m}, 10 \mathrm{H},-\left(\mathrm{CH}_{2}\right)_{5}-\mathrm{CH}_{3}, 0.88(\mathrm{t}, 3 \mathrm{H}\right.$, $\left.J=7.03 \mathrm{~Hz}, \mathrm{CH}_{3}\right) .{ }^{13} \mathrm{C}$ NMR $\left(\mathrm{CDCl}_{3}\right): 160.0$ (C5), 122.1 (C2), 114.5, 111.3, 111.0, 109.9 (C3, C4, C6, C7), 31.7, 30.9, 30.1, $29.0\left(\right.$ Int. $\left.=2 \mathrm{CH}_{2}\right), 28.8$, $\left.22.6\left(\mathrm{CH}_{2}\right)_{7}-\mathrm{CH}_{3}\right), 14.0\left(\mathrm{CH}_{3}\right) . \mathrm{Mp}=30-32{ }^{\circ} \mathrm{C} . R_{f}\left(\mathrm{CH}_{2} \mathrm{Cl}_{2} /\right.$ hexane $1 / 1$ $\mathrm{v} / \mathrm{v})=0.34 . \mathrm{C}_{14} \mathrm{H}_{17} \mathrm{Br}(79) \mathrm{N}_{2} \mathrm{~S}$ : EI-MS: $\left(\mathrm{M}^{+} \bullet\right)=324$.

4.2.19. 2-Octanoyl-3,4-dicyanothiophene (20). A mixture of 2-octanoyl-3,4-dibromothithiophene (19) $(2.90 \mathrm{~g}, 7.89 \mathrm{mmol})$ and $\mathrm{CuCN}$ $(2.12 \mathrm{~g}, 23.67 \mathrm{mmol})$ in dry $\mathrm{DMF}(15 \mathrm{~mL})$ was stirred under reflux for $4 \mathrm{~h}$. After cooling, the resulting dark solution was added to a solution of $\mathrm{FeCl}_{3}(8.10 \mathrm{~g})$ in $2 \mathrm{M} \mathrm{HCl}(15 \mathrm{~mL})$ and maintained at $70^{\circ} \mathrm{C}$ for $45 \mathrm{~min}$. After cooling to room temperature, this mixture was extracted three times with $\mathrm{CH}_{2} \mathrm{Cl}_{2}$. The organic layers were then combined and washed successively with $6 \mathrm{M} \mathrm{HCl}$ (two times), water, saturated $\mathrm{NaHCO}_{3}$ solution, and again with water. The organic layer was dried over $\mathrm{MgSO}_{4}$, filtrated, and then evaporated to dryness. The crude solid produced was then purified by chromatography on silica gel $\left(\mathrm{CH}_{2} \mathrm{Cl}_{2} /\right.$ hexane $\left.1 / 1 \mathrm{v} / \mathrm{v}\right)$ to afford $827 \mathrm{mg}(3.17 \mathrm{mmol})$ of a pale yellow solid. Yield: $40 \%$.

${ }^{1} \mathrm{H}$ NMR $\left(\mathrm{CD}_{2} \mathrm{Cl}_{2}\right): 8.24(\mathrm{~s}, 1 \mathrm{H}, \mathrm{H} 5), 3.06(\mathrm{t}, 2 \mathrm{H}, J=7.34 \mathrm{~Hz}$, $\left.-\mathrm{CO}-\mathrm{CH}_{2}-\right), 1.76\left(\mathrm{~m}, 2 \mathrm{H},-\mathrm{CO}-\mathrm{CH}_{2}-\mathrm{CH}_{2}-\right), 1.36(\mathrm{~m}, 8 \mathrm{H}$, $\left.-\left(\mathrm{CH}_{2}\right)_{4}-\mathrm{CH}_{3}\right), 0.89\left(\mathrm{t}, 3 \mathrm{H}, J=6.97 \mathrm{~Hz},-\mathrm{CH}_{3}\right) .{ }^{13} \mathrm{CNMR}\left(\mathrm{CD}_{2} \mathrm{Cl}_{2}\right): 190.8$ $(\mathrm{C}=\mathrm{O}), 152.0$ (C2), 140.9 (C5), 115. 7, 113.6 (C3, C4), 112.3, 112.0 (C6, C7), 41.4 (- $\left.\mathrm{CO}-\mathrm{CH}_{2}-\right), 32.2,29.5,29.4,24.3,23.1\left(-\left(\mathrm{CH}_{2}\right)_{5}-\mathrm{CH}_{3}\right)$, $14.4\left(-\mathrm{CH}_{3}\right) . \mathrm{Mp}=98-100^{\circ} \mathrm{C} . R_{f}\left(\mathrm{CH}_{2} \mathrm{Cl}_{2} /\right.$ hexane $\left.1 / 1 \mathrm{v} / \mathrm{v}\right)=0.09$. $\mathrm{C}_{14} \mathrm{H}_{16} \mathrm{~N}_{2} \mathrm{OS}$ : EI-HRMS ( $\mathrm{M}^{+} \bullet$ ): calcd: 260.0980; found: 260.0983.

4.2.20. 2-(2-Heptyl-1,3-dioxolan-2-yl)-3,4-dicyanothiophene (21). A mixture of 2-octanoyl-3,4-dicyanothiophene (20) (1.48 g, 5.68 mmol), ethylene glycol (2.22 mL, $2.47 \mathrm{~g}, 39.76 \mathrm{mmol})$, and $300 \mathrm{mg}$ of p-toluenesulfonic acid monohydrate in $80 \mathrm{~mL}$ of toluene was refluxed for $36 \mathrm{~h}$ with azeotropic removal of water (Dean-Stark apparatus). After cooling, the medium is washed with a saturated solution of $\mathrm{NaHCO}_{3}$ and with water. The organic layer was then dried over $\mathrm{MgSO}_{4}$, filtrated, and the solvent evaporated under vacuum. Compound 21 was used without further purification.

${ }^{1} \mathrm{H}$ NMR $\left(\mathrm{CD}_{2} \mathrm{Cl}_{2}\right): 7.94(\mathrm{~s}, 1 \mathrm{H}, \mathrm{H} 5), 4.03\left(\mathrm{~m}, 4 \mathrm{H},-\mathrm{O}-\left(\mathrm{CH}_{2}\right)_{2}-\mathrm{O}-\right)$, $2.07\left(\mathrm{~m}, 2 \mathrm{H},-\mathrm{C}\left(\left(\mathrm{OCH}_{2}\right)_{2}\right)-\mathrm{CH}_{2}-\right), 1.30\left(\mathrm{~m}, 10 \mathrm{H},-\left(\mathrm{CH}_{2}\right)_{5}-\mathrm{CH}_{3}\right), 0.87$ $\left(\mathrm{t}, 3 \mathrm{H}, J=6.97 \mathrm{~Hz}, \mathrm{CH}_{3}\right) .{ }^{13} \mathrm{C}$ NMR $\left(\mathrm{CD}_{2} \mathrm{Cl}_{2}\right): 161.4(\mathrm{C} 2), 136.3$ (C5), 114.1, 112.7, 112.1, 109.1 (C3, C4, C6, C7), $108.8\left(\mathrm{C} 2-\mathrm{C}\left(\left(\mathrm{OCH}_{2}\right)_{2}\right)-\right)$, $66.4 \quad\left(-\mathrm{O}-\left(\mathrm{CH}_{2}\right)_{2}-\mathrm{O}-\right), \quad 40.1, \quad 32.3, \quad 29.9, \quad 29.6, \quad 23.9, \quad 23.2$ $\left(-\left(\mathrm{CH}_{2}\right)_{6}-\mathrm{CH}_{3}\right), 14.4\left(\mathrm{CH}_{3}\right) . \quad R_{f}\left(\mathrm{CH}_{2} \mathrm{Cl}_{2} /\right.$ hexane $\left.1 / 1 \mathrm{v} / \mathrm{v}\right)=0.07$. $\mathrm{C}_{16} \mathrm{H}_{20} \mathrm{~N}_{2} \mathrm{O}_{2} \mathrm{~S}$ : EIMS $\left(\mathrm{M}^{+}-\mathrm{C}_{7} \mathrm{H}_{15}\right)$ : 205.

4.2.21. 2-Bromo-5-(2-heptyl-1,3-dioxolan-2-yl)-3,4-dicyanothiophene (22). A solution of $1.08 \mathrm{~g}$ of 2-octanoyl-3,4-dicyanothiophene (21) in dry THF $(30 \mathrm{~mL})$ was cooled to $-80^{\circ} \mathrm{C}$ under argon and $2.97 \mathrm{~mL}$ of LDA (1.8 M in solution in THF/n-heptane/ethylbenzene) was added dropwise. The mixture was then stirred for
$10 \mathrm{~min}$, then $0.450 \mathrm{~mL}$ of bromine $(1.39 \mathrm{~g}, 4.3 \mathrm{mmol})$ was slowly added. The medium was then allowed to warm to $-50{ }^{\circ} \mathrm{C}(30 \mathrm{~min})$. After adding a saturated solution of $\mathrm{NaCl}(20 \mathrm{~mL})$, the solution was extracted with $\mathrm{CH}_{2} \mathrm{Cl}_{2}$. The organic layers were dried over $\mathrm{MgSO}_{4}$, filtrated, and concentrated. The brown liquid residue was dissolved in $\mathrm{CH}_{2} \mathrm{Cl}_{2}(5 \mathrm{~mL})$ and purified by column chromatography on silica gel $\left(\mathrm{CH}_{2} \mathrm{Cl}_{2}\right)$ to give a yellow liquid, which crystallized in the fridge (863 mg, $2.25 \mathrm{mmol}$ ). Yield: 40\% (from 20).

${ }^{1} \mathrm{H}$ NMR $\left(\mathrm{CD}_{2} \mathrm{Cl}_{2}\right): 4.02\left(\mathrm{~m}, 4 \mathrm{H},-\mathrm{O}-\left(\mathrm{CH}_{2}\right)_{2}-\mathrm{O}-\right), 2.04(\mathrm{~m}, 2 \mathrm{H},-\mathrm{C}$ $\left.\left(\left(\mathrm{OCH}_{2}\right)_{2}\right)-\mathrm{CH}_{2}-\right), 1.30\left(\mathrm{~m}, 10 \mathrm{H},-\left(\mathrm{CH}_{2}\right)_{5}-\mathrm{CH}_{3}\right), 0.87(\mathrm{t}, 3 \mathrm{H}$, $\left.J=6.97 \mathrm{~Hz}, \mathrm{CH}_{3}\right) .{ }^{13} \mathrm{C}$ NMR $\left(\mathrm{CD}_{2} \mathrm{Cl}_{2}\right): 161.9$ (C5), 124.6 (C2), 116.8, 111.9, 111.3, 109.0 (C3, C4, C6, C7), $108.8\left(\mathrm{C} 5-\mathrm{C}\left(\left(\mathrm{OCH}_{2}\right)_{2}\right)-\right), 66.5$ $\left(-\mathrm{O}-\left(\mathrm{CH}_{2}\right)_{2}-\mathrm{O}-\right), 39.8,32.2,29.8,29.6,23.8,23.2\left(-\left(\mathrm{CH}_{2}\right)_{6}-\mathrm{CH}_{3}\right)$, $14.4\left(\mathrm{CH}_{3}\right) . \mathrm{Mp}=35-37^{\circ} \mathrm{C} . R_{f}\left(\mathrm{CH}_{2} \mathrm{Cl}_{2}\right)=0.68 . \mathrm{C}_{16} \mathrm{H}_{19} \mathrm{Br}(79) \mathrm{N}_{2} \mathrm{O}_{2} \mathrm{~S}$ : EIMS $\left(\mathrm{M}^{+} \cdot\right): 382$.

4.2.22. 5-Octyl-3,4-dicyano-2,2'-bithiophene (24). 2-Bromo-5-octyl3,4-dicyanothiophène $(\mathbf{1 8})(800.0 \mathrm{mg}, 2.46 \mathrm{mmol})$ and 2-(tributylstannyl)thiophene (1.832 g, $1.56 \mathrm{~mL}, 4.91 \mathrm{mmol}$ ) were dissolved in dry $\mathrm{DMF}(28 \mathrm{~mL})$ under argon. To this solution was added $\mathrm{Pd}\left(\mathrm{PPh}_{3}\right)_{4}$ (250 mg) and the mixture was heated at $70-80{ }^{\circ} \mathrm{C}$ for $2 \mathrm{~h}$. After cooling, $50 \mathrm{~mL}$ of saturated solution of ammonium chloride was added and the medium was extracted twice with $\mathrm{CH}_{2} \mathrm{Cl}_{2}$. The combined organic phases were washed twice with water and dried over $\mathrm{MgSO}_{4}$. After filtration, the solvent was removed under vacuum. Purification by column chromatography on silica gel $\left(\mathrm{CH}_{2} \mathrm{Cl}_{2}\right)$ afforded $750 \mathrm{mg}$ (2.28 mmol) of 5-octyl-3,4-dicyano-2,2'-bithiophene (24) as a white solid. Yield: 93\%.

${ }^{1} \mathrm{H} \mathrm{NMR}\left(\mathrm{CDCl}_{3}\right): 7.61\left(\mathrm{dd}, 1 \mathrm{H}, J=1.11\right.$ and $\left.3.75 \mathrm{~Hz}, \mathrm{H3}^{\prime}\right), 7.48$ (dd, $1 \mathrm{H}, J=1.11$ and $\left.5.10 \mathrm{~Hz}, \mathrm{H}^{\prime}\right) 7.14\left(\mathrm{dd}, 1 \mathrm{H}, J=3.75\right.$ and $5.10 \mathrm{~Hz}, \mathrm{H} 4^{\prime}$ ), $2.98\left(\mathrm{t}, 2 \mathrm{H}, \mathrm{J}=7.71 \mathrm{~Hz},-\mathrm{CH}_{2}-\mathrm{C}_{7} \mathrm{H}_{15}\right), 1.74\left(\mathrm{~m}, 2 \mathrm{H},-\mathrm{CH}_{2}-\mathrm{CH}_{2}-\mathrm{C}_{6} \mathrm{H}_{13}\right)$, $1.29\left(\mathrm{~m}, 10 \mathrm{H},-\left(\mathrm{CH}_{2}\right)_{5}-\mathrm{CH}_{3}\right), 0.88\left(\mathrm{t}, 3 \mathrm{H}, J=7.00 \mathrm{~Hz}, \mathrm{CH}_{3}\right) .{ }^{13} \mathrm{C} \mathrm{NMR}$ $\left(\mathrm{CDCl}_{3}\right)$ : 156.4 (C5), 145.6(C2), 131.6 (C2'), 128.8, 128.5, 128.2 (C3', C4', $\mathrm{C}^{\prime}$ ), 113.0, 111.9, 110.4, 104.9 (C3, C4, C6, C7), 31.7, 31.0, 29.7, 29.0 (Int. $\left.=2 \mathrm{CH}_{2}\right), 28.8,22.6\left(\left(\mathrm{CH}_{2}\right)_{7}-\mathrm{CH}_{3}\right), 14.0\left(\mathrm{CH}_{3}\right) . \mathrm{Mp}=74-75^{\circ} \mathrm{C} . R_{f}$ $\left(\mathrm{CH}_{2} \mathrm{Cl}_{2}\right)=0.75 . \mathrm{C}_{18} \mathrm{H}_{20} \mathrm{~N}_{2} \mathrm{~S}_{2}$ : EIMS $\left(\mathrm{M}^{+} \bullet\right): 328$.


$2,2^{\prime}: 5^{\prime}, 2^{\prime \prime}: 5^{\prime \prime}, 2^{\prime \prime \prime}$-quaterthiophene (25). A mixture of $5^{\prime}$-bromo-5-(2heptyl-1,3-dioxolan-2-yl)-3,4-dicyano-2,2'-bithiophene (30) (321.0 $\mathrm{mg}, \quad 0.69 \mathrm{mmol}), \quad \mathrm{Pd}(\mathrm{OAc})_{2}(110 \mathrm{mg}, 0.49 \mathrm{mmol})$, and $i-\mathrm{Pr}_{2} \mathrm{EtN}$ $(89.1 \mathrm{mg}, 118 \mu \mathrm{L}, 0.69 \mathrm{mmol})$ in toluene $(15 \mathrm{~mL})$ was refluxed under argon for $4 \mathrm{~h}$. After cooling to room temperature, the solvent was evaporated in vacuo. The residue was then dissolved in $\mathrm{CH}_{2} \mathrm{Cl}_{2}$ and purification by column chromatography on silica gel $\left(\mathrm{CH}_{2} \mathrm{Cl}_{2}\right)$ gave an orange solid (131.0 mg, $0.17 \mathrm{mmol}$ ). Yield: $49 \%$.

${ }^{1} \mathrm{H} \mathrm{NMR}\left(\mathrm{CDCl}_{3}\right): 7.58$ (d, 2H, $\left.J=3.98 \mathrm{~Hz}, \mathrm{H}^{\prime}, \mathrm{H}^{\prime \prime}\right), 7.28(\mathrm{~d}, 2 \mathrm{H}$, $\left.J=3.98 \mathrm{~Hz}, \mathrm{H}^{\prime \prime}, \mathrm{H} 4^{\prime}\right), 4.08\left(\mathrm{~m}, 8 \mathrm{H},-\mathrm{O}-\left(\mathrm{CH}_{2}\right)_{2}-\mathrm{O}-\right), 2.09(\mathrm{~m}, 4 \mathrm{H},-\mathrm{C}$ $\left.\left(\left(\mathrm{OCH}_{2}\right)_{2}\right)-\mathrm{CH}_{2}-\right), 1.33\left(\mathrm{~m}, 2 \mathrm{H},-\left(\mathrm{CH}_{2}\right)_{5}-\mathrm{CH}_{3}\right), 0.88(\mathrm{t}, 3 \mathrm{H}$, $\left.J=6.97 \mathrm{~Hz}, \mathrm{CH}_{3}\right) .{ }^{13} \mathrm{C} \mathrm{NMR}\left(\mathrm{CDCl}_{3}\right): 157.6\left(\mathrm{C}, \mathrm{C}^{\prime \prime \prime}\right), 145.6\left(\mathrm{C} 2, \mathrm{C}^{\prime \prime \prime}\right)$, $139.2\left(\mathrm{C}^{\prime}, \mathrm{C}^{\prime \prime}\right), 131.4\left(\mathrm{C}^{\prime}, \mathrm{C} 5^{\prime \prime}\right), 129.5,126.1\left(\mathrm{C}^{\prime}, \mathrm{C}^{\prime}, \mathrm{C}^{\prime \prime}, \mathrm{C}^{\prime \prime}\right)$, 112.7, 111.3 (C6, C6', C7, C7'), $109.4\left(\mathrm{C} 4, \mathrm{C}^{\prime \prime \prime}\right), 108.2$ (C5-C $\left.\left(\left(\mathrm{OCH}_{2}\right)_{2}\right)-\right), 106.9\left(\mathrm{C} 3, \mathrm{C}^{\prime \prime \prime}\right), 65.8\left(-\mathrm{O}-\left(\mathrm{CH}_{2}\right)_{2}-\mathrm{O}-\right), 39.5,31.7$, 29.3, 29.1, 23.3, $22.6\left(-\left(\mathrm{CH}_{2}\right)_{6}-\mathrm{CH}_{3}\right), 14.0\left(\mathrm{CH}_{3}\right) . \mathrm{Mp}=198-200{ }^{\circ} \mathrm{C}$. $\mathrm{C}_{40} \mathrm{H}_{42} \mathrm{~N}_{4} \mathrm{O}_{4} \mathrm{~S}_{4}$ : MALDI-MS $\left(\mathrm{M}^{+} \bullet\right)$ : 770.2 .

4.2.24. 5-(2-Heptyl-1,3-dioxolan-2-yl)-3,4-dicyano-2,2'-bithiophene (26). 2-Bromo-5-(2-heptyl-1,3-dioxolan-2-yl)-3,4-dicyanothiophene (22) (0.608 g, $1.59 \mathrm{mmol}$ ) and 2-(tributylstannyl)thiophène (1.184 g, $1.00 \mathrm{~mL}, 3.17 \mathrm{mmol}$ ) were dissolved in dry $\mathrm{DMF}(15 \mathrm{~mL})$ under argon. To this solution was added $\mathrm{Pd}\left(\mathrm{PPh}_{3}\right)_{4}(150 \mathrm{mg})$ and the mixture was heated at $70-80^{\circ} \mathrm{C}$ for $3 \mathrm{~h}$. After cooling, $40 \mathrm{~mL}$ of saturated solution of $\mathrm{NH}_{4} \mathrm{Cl}$ was added and the mixture was extracted twice with $\mathrm{CH}_{2} \mathrm{Cl}_{2}$. The combined organic phases were then washed twice with water and dried over $\mathrm{MgSO}_{4}$. After filtration, the solvent was removed under vacuum. Purification by column chromatography on 
silica gel $\left(\mathrm{CH}_{2} \mathrm{Cl}_{2}+2 \% \mathrm{Et}_{3} \mathrm{~N}\right)$ afforded $536.9 \mathrm{mg}$ (1.39 mmol) of desired bithiophene $\mathbf{2 6}$ as a pale yellow waxy solid. Yield: $87 \%$.

${ }^{1} \mathrm{H} \mathrm{NMR}\left(\mathrm{CDCl}_{3}\right): 7.63\left(\mathrm{dd}, 1 \mathrm{H}, J=1.09 \mathrm{~Hz}\right.$ and $\left.3.76 \mathrm{~Hz}, \mathrm{H3}^{\prime}\right), 7.51$ (dd, $1 \mathrm{H}, J=1.09 \mathrm{~Hz}$ and $5.10 \mathrm{~Hz}, \mathrm{H} 5^{\prime}$ ), $7.15(\mathrm{dd}, 1 \mathrm{H}, J=3.76 \mathrm{~Hz}$ and $\left.5.09 \mathrm{~Hz}, \mathrm{H} 4^{\prime}\right), 4.07\left(\mathrm{~m}, 4 \mathrm{H},-\mathrm{O}-\left(\mathrm{CH}_{2}\right)_{2}-\mathrm{O}-\right), 2.09(\mathrm{~m}, 2 \mathrm{H},-\mathrm{C}$ $\left.\left(\left(\mathrm{OCH}_{2}\right)_{2}\right)-\mathrm{CH}_{2}-\right), 1.31\left(\mathrm{~m}, 10 \mathrm{H},-\left(\mathrm{CH}_{2}\right)_{5}-\mathrm{CH}_{3}\right), 0.87(\mathrm{t}, 3 \mathrm{H}$, $\left.J=6.92 \mathrm{~Hz}, \mathrm{CH}_{3}\right) .{ }^{13} \mathrm{C} \mathrm{NMR}\left(\mathrm{CDCl}_{3}\right): 157.2(\mathrm{C} 5), 146.7(\mathrm{C} 2), 131.4\left(\mathrm{C2}^{\prime}\right)$, 129.2, 128.6, $128.5\left(\mathrm{C} 3^{\prime}, \mathrm{C}^{\prime}, \mathrm{C}^{\prime}\right), 112.8,111.4,(\mathrm{C} 6, \mathrm{C} 7), 109.1$ (C4), $108.2\left(\mathrm{C} 5-\mathrm{C}\left(\left(\mathrm{OCH}_{2}\right)_{2}\right)-\right), 106.7\left(\mathrm{C}_{3}\right), 65.7\left(-\mathrm{O}-\left(\mathrm{CH}_{2}\right)_{2}-\mathrm{O}-\right), 39.5$, 31.7, 29.3, 29.1, 23.3, $22.6\left(-\left(\mathrm{CH}_{2}\right)_{6}-\mathrm{CH}_{3}\right), \quad 14.0 \quad\left(\mathrm{CH}_{3}\right)$. $\mathrm{Mp}=57-59^{\circ} \mathrm{C} . R_{f}\left(\mathrm{CH}_{2} \mathrm{Cl}_{2}\right)=0.66 . \mathrm{C}_{20} \mathrm{H}_{22} \mathrm{~N}_{2} \mathrm{O}_{2} \mathrm{~S}_{2}$ : EIMS $\left(\mathrm{M}^{+} \bullet\right): 386$.

4.2.25. 5,5'-Bis(heptyl-1,3-dioxolan-2-yl)-3,3',4,4'-tetracyano-2,2'bithiophene (28). A mixture of 2-bromo-5-(2-heptyl-1,3-dioxolan2-yl)-3,4-dicyanothiophene (22) (230.0 mg, $0.60 \mathrm{mmol}), \mathrm{Pd}(\mathrm{OAc})_{2}$ (60 mg, $0.27 \mathrm{mmol}$ ), and $i-\mathrm{Pr}_{2} \mathrm{EtN}(77.5 \mathrm{mg}, 103 \mu \mathrm{L}, 0.60 \mathrm{mmol}$ ) in toluene $(10 \mathrm{~mL})$ was refluxed under argon for $2 \mathrm{~h}$. After cooling to room temperature, the mixture was purified by column chromatography on silica gel $\left(\mathrm{CH}_{2} \mathrm{Cl}_{2}\right)$ to give a white solid (90 mg, $0.15 \mathrm{mmol})$. Yield: $49 \%$.

${ }^{1} \mathrm{H}$ NMR $\left(\mathrm{CDCl}_{3}\right): 4.07\left(\mathrm{~m}, 4 \mathrm{H},-\mathrm{O}-\left(\mathrm{CH}_{2}\right)_{2}-\mathrm{O}-\right), 2.11(\mathrm{~m}, 2 \mathrm{H},-\mathrm{C}$ $\left.\left(\left(\mathrm{OCH}_{2}\right)_{2}\right)-\mathrm{CH}_{2}-\right), 1.33\left(\mathrm{~m}, 10 \mathrm{H},-\left(\mathrm{CH}_{2}\right)_{5}-\mathrm{CH}_{3}\right), 0.88(\mathrm{t}, 3 \mathrm{H}$, $\left.\mathrm{J}=6.95 \mathrm{~Hz}, \mathrm{CH}_{3}\right) .{ }^{13} \mathrm{C} \mathrm{NMR}\left(\mathrm{CDCl}_{3}\right): 162.2\left(\mathrm{C} 5, \mathrm{C}^{\prime}\right), 138.8\left(\mathrm{C} 2, \mathrm{C}^{\prime}\right)$, $112.8,111.4,110.6,110.0\left(\mathrm{C}^{\prime}, \mathrm{C}^{\prime}, \mathrm{C} 4, \mathrm{C} 4, \mathrm{C} 6, \mathrm{C}^{\prime}, \mathrm{C} 7, \mathrm{C}^{\prime}\right), 108.2$ (C5) $\left.5^{\prime}-\mathrm{C}\left(\left(\mathrm{OCH}_{2}\right)_{2}\right)-\right), 66.0\left(-\mathrm{O}-\left(\mathrm{CH}_{2}\right)_{2}-\mathrm{O}-\right)$, 39.4, 31.7, 29.2, 29.1, 23.2, $22.6\left(-\left(\mathrm{CH}_{2}\right)_{6}-\mathrm{CH}_{3}\right), 14.0\left(\mathrm{CH}_{3}\right) . \mathrm{Mp}=174-175^{\circ} \mathrm{C} . R_{f}\left(\mathrm{CH}_{2} \mathrm{Cl}_{2}\right)=0.59$. $\mathrm{C}_{32} \mathrm{H}_{36} \mathrm{~N}_{4} \mathrm{O}_{4} \mathrm{~S}_{2}$ : EIMS $\left(\mathrm{M}^{+} \bullet\right): 606$.

4.2.26. 5'-Bromo-5-octyl-3,4-dicyano-2,2'-bithiophene (29). 5Octyl-3,4-dicyano-2,2'-bithiophene (24) (106.5 $\mathrm{mg}, 0.32 \mathrm{mmol})$ was dissolved in chloroform $(10 \mathrm{~mL})$ and bromine $(51 \mu \mathrm{L}, 159.0 \mathrm{mg}$, $0.49 \mathrm{mmol}$ ) was added dropwise. After stirring for $15 \mathrm{~min}$ at room temperature the mixture was washed with a solution of $\mathrm{Na}_{2} \mathrm{~S}_{2} \mathrm{O}_{3}$ and with water. The organic layer was dried over $\mathrm{MgSO}_{4}$. After filtration, the solvent was removed under vacuum to afford pure product as a pale yellow solid (101 $\mathrm{mg}, 0.25 \mathrm{mmol})$. Yield: $78 \%$.

${ }^{1} \mathrm{H}$ NMR $\left(\mathrm{CDCl}_{3}\right): 7.34\left(\mathrm{~d}, 1 \mathrm{H}, J=4.00 \mathrm{~Hz}, \mathrm{H3}^{\prime}\right), 7.11(\mathrm{~d}, 1 \mathrm{H}$, $\left.J=4.00 \mathrm{~Hz}, \mathrm{H}^{\prime}\right), 2.98\left(\mathrm{t}, 2 \mathrm{H}, J=7.53 \mathrm{~Hz},-\mathrm{CH}_{2}-\mathrm{C}_{7} \mathrm{H}_{15}\right), 1.74(\mathrm{~m}, 2 \mathrm{H}$, $\left.-\mathrm{CH}_{2}-\mathrm{CH}_{2}-\mathrm{C}_{6} \mathrm{H}_{12}\right), 1.29\left(\mathrm{~m}, 10 \mathrm{H},-\left(\mathrm{CH}_{2}\right)_{5}-\mathrm{CH}_{3}, 0.89(\mathrm{t}, 3 \mathrm{H}\right.$, $\left.J=6.98 \mathrm{~Hz}, \mathrm{CH}_{3}\right) .{ }^{13} \mathrm{C} \mathrm{NMR}\left(\mathrm{CDCl}_{3}\right): 156.7(\mathrm{C} 5), 144.3(\mathrm{C} 2), 132.9\left(\mathrm{C2}^{\prime}\right)$, 131.3, 128.5 (C3', C4'), $116.6\left(\mathrm{C5}^{\prime}\right), 112.8,111.7,110.5,105.3$ (C3, C4, C6, C7), 31.7, 31.0, 29.8, $29.0\left(\right.$ Int. $\left.\left.=2 \mathrm{CH}_{2}\right), 28.9,22.6,\left(\mathrm{CH}_{2}\right)_{7}-\mathrm{CH}_{3}\right)$, $14.1\left(\mathrm{CH}_{3}\right) . \mathrm{Mp}=92-94^{\circ} \mathrm{C} . R_{f}\left(\mathrm{CH}_{2} \mathrm{Cl}_{2}\right)=0.79 . \quad \mathrm{C}_{20} \mathrm{H}_{22} \mathrm{Br}(79) \mathrm{N}_{2} \mathrm{~S}_{2}$ : EIMS $\left(\mathrm{M}^{+} \bullet\right): 406$.

4.2.27. 5'-Bromo-5-(2-heptyl-1,3-dioxolan-2-yl)-3,4-dicyano-2,2'bithiophene (30). To a solution of 5-(2-heptyl-1,3-dioxolan-2-yl)3,4-dicyano-2,2'-bithiophene (26) (600.0 mg, $1.55 \mathrm{mmol}$ ) in $\mathrm{CH}_{2} \mathrm{Cl}_{2}$ $(30 \mathrm{~mL})$ was added $\mathrm{Et}_{3} \mathrm{~N}(250 \mu \mathrm{L}, 182.1 \mathrm{mg}, 1.80 \mathrm{mmol})$. Bromine ( $191 \mu \mathrm{L}, 595.0 \mathrm{mg}, 3.72 \mathrm{mmol}$ ) was added in one portion. The medium was stirred at room temperature for $2 \mathrm{~h}$. The reaction medium was diluted with $\mathrm{CH}_{2} \mathrm{Cl}_{2}(60 \mathrm{~mL})$ and successively washed twice with $\mathrm{Na}_{2} \mathrm{~S}_{2} \mathrm{O}_{3}$ solution and once with water. The organic layer was dried over $\mathrm{MgSO}_{4}$, filtrated, and concentrated under vacuum. Filtration through a silica gel pad $\left(\mathrm{CH}_{2} \mathrm{Cl}_{2}\right)$ afforded the desired brominated bithiophene $\mathbf{3 0}$ as a pale yellow solid (464.0 mg, $1.00 \mathrm{mmol})$. Yield: $64 \%$.

${ }^{1} \mathrm{H}$ NMR $\left(\mathrm{CDCl}_{3}\right): 7.35\left(\mathrm{~d}, 1 \mathrm{H}, J=4.00 \mathrm{~Hz}, \mathrm{H}^{\prime}\right), 7.11(\mathrm{~d}, 1 \mathrm{H}$, $\left.J=4.00 \mathrm{~Hz}, \mathrm{H}^{\prime}\right), 4.06\left(\mathrm{~m}, 4 \mathrm{H},-\mathrm{O}-\left(\mathrm{CH}_{2}\right)_{2}-\mathrm{O}-\right), 2.06(\mathrm{~m}, 2 \mathrm{H},-\mathrm{C}$ $\left.\left(\left(\mathrm{OCH}_{2}\right)_{2}\right)-\mathrm{CH}_{2}-\right), 1.33\left(\mathrm{~m}, 10 \mathrm{H},-\left(\mathrm{CH}_{2}\right)_{5}-\mathrm{CH}_{3}\right), 0.88(\mathrm{t}, 3 \mathrm{H}$, $\left.J=7.00 \mathrm{~Hz}, \mathrm{CH}_{3}\right) \cdot{ }^{13} \mathrm{C} \mathrm{NMR}\left(\mathrm{CDCl}_{3}\right): 157.6(\mathrm{C} 5), 145.4(\mathrm{C} 2), 132.7\left(\mathrm{C2}^{\prime}\right)$, 131.4, $128.8\left(\mathrm{C}^{\prime}, \mathrm{C}^{\prime}\right), 117.0\left(\mathrm{C5}^{\prime}\right)$ 112.5, 111.3, (C6, C7), 109.2 (C4), $108.2\left(\mathrm{C} 5-\mathrm{C}\left(\left(\mathrm{OCH}_{2}\right)_{2}\right)-\right), 107.07\left(\mathrm{C}_{3}\right), 65.8\left(-\mathrm{O}-\left(\mathrm{CH}_{2}\right)_{2}-\mathrm{O}-\right), 39.5$, 31.7, 29.3, 29.1, 23.3, $22.6\left(-\left(\mathrm{CH}_{2}\right)_{6}-\mathrm{CH}_{3}\right), 14.0\left(\mathrm{CH}_{3}\right) . \mathrm{Mp}=69-71^{\circ} \mathrm{C}$. $R_{f}\left(\mathrm{CH}_{2} \mathrm{Cl}_{2}\right)=0.72 . \mathrm{C}_{20} \mathrm{H}_{21} \mathrm{Br}(79) \mathrm{N}_{2} \mathrm{O}_{2} \mathrm{~S}_{2}$ : EIMS $\left(\mathrm{M}^{+} \bullet\right): 464$.
4.2.28. 2-Bromo-3,4-dicyanothiophene (31). 2,5-Dibromo-3,4-dicyanothiophene (10) $(500.0 \mathrm{mg}, 1.71 \mathrm{mmol})$ and $\mathrm{Pd}\left(\mathrm{PPh}_{3}\right)_{4}(200 \mathrm{mg}$, $0.17 \mathrm{mmol}$ ) were heated at $70^{\circ} \mathrm{C}$ in $\mathrm{CH}_{3} \mathrm{CN}(40 \mathrm{~mL})$ under argon for $10 \mathrm{~min}$. Then $\mathrm{NaBH}_{4}(65.0 \mathrm{mg}, 1.71 \mathrm{mmol})$ was added in portions. After $45 \mathrm{~min}$, the reaction was stopped by adding $30 \mathrm{~mL}$ of water. This mixture was extracted with $\mathrm{CH}_{2} \mathrm{Cl}_{2}$ and the organic layer was dried over $\mathrm{MgSO}_{4}$, filtrated, and then evaporated to dryness. The solid residue was purified by column chromatography on silica gel $\left(\mathrm{CH}_{2} \mathrm{Cl}_{2}\right)$ to give $259 \mathrm{mg}$ (1.21 mmol) of a pale yellow solid. Yield: $71 \%$.

${ }^{1} \mathrm{H} \mathrm{NMR}\left(\mathrm{CDCl}_{3}\right): 7.97$ (s, $\left.1 \mathrm{H}, \mathrm{H} 5\right) .{ }^{13} \mathrm{C} \mathrm{NMR}\left(\mathrm{CDCl}_{3}\right): 137.4(\mathrm{C} 5)$, 125.9 (C2), 115.6, 113.2 (C3, C4), 111.0, 110.9 (C6, C7). $\mathrm{Mp}=132-135^{\circ} \mathrm{C} . R_{f}\left(\mathrm{CH}_{2} \mathrm{Cl}_{2}\right)=0.62 . \mathrm{C}_{6} \mathrm{HBr}(79) \mathrm{N}_{2} \mathrm{~S}: \operatorname{EIMS}\left(\mathrm{M}^{+} \bullet\right): 212$.

4.2.29. 5'-Octyl-3,4-dicyano-2,2'-bithiophene (32). A mixture of 2bromo-3,4-dicyanothiophene (31) $(0.418 \mathrm{~g}, 1.96 \mathrm{mmol}), \mathrm{Pd}\left(\mathrm{PPh}_{3}\right)_{4}$ (0.220 g, $0.19 \mathrm{mmol})$, and 2-octyl-5-tributylstannylthiophene (15) $(1.940 \mathrm{~g}, 4.00 \mathrm{mmol})$ was heated at $80^{\circ} \mathrm{C}$ in dry DMF $(20 \mathrm{~mL})$ under argon during $4.5 \mathrm{~h}$. After cooling, a saturated solution of $\mathrm{NH}_{4} \mathrm{Cl}$ $\left(40 \mathrm{~mL}\right.$ ) was added and the mixture extracted with $\mathrm{CH}_{2} \mathrm{Cl}_{2}$. The organic layer was then washed with $\mathrm{H}_{2} \mathrm{O}$, dried over $\mathrm{MgSO}_{4}$, filtrated and concentrated under vacuum. The residue was purified by column on silica gel $\left(\mathrm{CH}_{2} \mathrm{Cl}_{2} /\right.$ hexane $\left.7 / 3 \mathrm{v} / \mathrm{v}\right)$ to afford the desired bithiophene 32 (520 mg, $1.58 \mathrm{mmol})$ as a white solid. Yield: $81 \%$.

${ }^{1} \mathrm{H}$ NMR $\left(\mathrm{CDCl}_{3}\right): 7.76$ (s, 1H, H5), 7.49 (d, $\left.1 \mathrm{H}, J=3.75 \mathrm{~Hz}, \mathrm{H} 4^{\prime}\right)$, $6.83\left(\mathrm{~d}, 1 \mathrm{H}, J=3.75 \mathrm{~Hz}, \mathrm{H3}^{\prime}\right), 2.84\left(\mathrm{t}, 2 \mathrm{H}, J=7.56 \mathrm{~Hz},-\mathrm{CH}_{2}-\mathrm{C}_{7} \mathrm{H}_{15}\right)$, $1.70\left(\mathrm{~m}, 2 \mathrm{H},-\mathrm{CH}_{2}-\mathrm{CH}_{2}-\mathrm{C}_{6} \mathrm{H}_{13}\right), 1.32\left(\mathrm{~m}, 10 \mathrm{H},-\left(\mathrm{CH}_{2}\right)_{5}-\mathrm{CH}_{3}\right), 0.88$ $\left(\mathrm{t}, 3 \mathrm{H}, J=6.94 \mathrm{~Hz}, \mathrm{CH}_{3}\right) .{ }^{13} \mathrm{C} \mathrm{NMR}\left(\mathrm{CDCl}_{3}\right): 151.4\left(\mathrm{C}^{\prime}\right), 149.3(\mathrm{C} 2)$, 133.0 (C5), 128.9 (C4'), $128.5\left(\mathrm{C}^{\prime}\right), 125.8\left(\mathrm{C}^{\prime}\right), 113.4,112.9,112.0$, 109.5 (C3, C4, C6, C7), 31.8, 31.4, 30.2, 29.2, 29.1, 29.0, 22.6 $\left(-\left(\mathrm{CH}_{2}\right)_{7}-\mathrm{CH}_{3}\right), 14.1\left(\mathrm{CH}_{3}\right) . \mathrm{Mp}=56-58{ }^{\circ} \mathrm{C} . R_{f}\left(\mathrm{CH}_{2} \mathrm{Cl}_{2} /\right.$ hexane $7 / 3$ $\mathrm{v} / \mathrm{v})=0.56 . \mathrm{C}_{18} \mathrm{H}_{20} \mathrm{~N}_{2} \mathrm{~S}_{2}$ : EIMS $\left(\mathrm{M}^{+} \bullet\right): 328$.

4.2.30. 5-Bromo-5'-octyl-3,4-dicyano-2,2'-bithiophene (33). A solution of $5^{\prime}$-octyl-3,4-dicyano-2,2'-bithiophene (32) $(335.0 \mathrm{mg}$, $1.02 \mathrm{mmol})$ in dry THF $(30 \mathrm{~mL})$ was cooled at $-80^{\circ} \mathrm{C}$ under argon and LDA (1.13 mL, $2.04 \mathrm{mmol}$ ) (1.8 $\mathrm{M}$ in solution in THF/n-heptane/ ethylbenzene) was added dropwise. The mixture was stirred for $10 \mathrm{~min}$, then bromine ( $78 \mu \mathrm{L}, 245.0 \mathrm{mg}, 1.53 \mathrm{mmol}$ ) was slowly added. The mixture was stirred for $2 \mathrm{~h}$ at $-80^{\circ} \mathrm{C}$. After adding a saturated solution of $\mathrm{NH}_{4} \mathrm{Cl}(40 \mathrm{~mL})$, the solution was extracted with $\mathrm{CH}_{2} \mathrm{Cl}_{2}$. The organic layers were dried over $\mathrm{MgSO}_{4}$, filtrated, and concentrated. The residue was purified by column chromatography on silica gel $\left(\mathrm{CH}_{2} \mathrm{Cl}_{2} /\right.$ hexane $\left.7 / 3 \mathrm{v} / \mathrm{v}\right)$ to give a pale yellow solid (160.0 mg, $0.38 \mathrm{mmol}$ ). Yield: $38 \%$.

${ }^{1} \mathrm{H} \mathrm{NMR}\left(\mathrm{CDCl}_{3}\right): 7.44\left(\mathrm{~d}, 1 \mathrm{H}, J=3.77 \mathrm{~Hz}, \mathrm{H} 4^{\prime}\right), 6.83(\mathrm{~d}, 1 \mathrm{H}, J=3.77 \mathrm{~Hz}$, $\left.\mathrm{H3}^{\prime}\right), 2.82\left(\mathrm{t}, 2 \mathrm{H}, \quad J=7.54 \mathrm{~Hz}, \quad-\mathrm{CH}_{2}-\mathrm{C}_{7} \mathrm{H}_{15}\right), 1.70(\mathrm{~m}, \quad 2 \mathrm{H}$, $\left.-\mathrm{CH}_{2}-\mathrm{CH}_{2}-\mathrm{C}_{6} \mathrm{H}_{13}\right), 1.31\left(\mathrm{~m}, 10 \mathrm{H},-\left(\mathrm{CH}_{2}\right)_{5}-\mathrm{CH}_{3}\right), 0.89(\mathrm{t}, 3 \mathrm{H}, J=6.96 \mathrm{~Hz}$, $\left.\mathrm{CH}_{3}\right) .{ }^{13} \mathrm{C} \mathrm{NMR}\left(\mathrm{CDCl}_{3}\right): 152.1\left(\mathrm{C}^{\prime}\right), 149.6(\mathrm{C} 2), 129.1\left(\mathrm{C}^{\prime}\right), 127.9\left(\mathrm{C}^{\prime}\right)$, 125.9(C3'), 121.2(C5), 115.9, 112.2, 111.2, 104.5 (C3, C4, C6, C7), 31.8, 31.4, $30.2,29.2,29.1,29.0,22.6\left(-\left(\mathrm{CH}_{2}\right)_{7}-\mathrm{CH}_{3}\right), 14.1\left(\mathrm{CH}_{3}\right) . \mathrm{Mp}=102-104{ }^{\circ} \mathrm{C}$. $R_{f}\left(\mathrm{CH}_{2} \mathrm{Cl}_{2} /\right.$ hexane $\left.7 / 3 \mathrm{v} / \mathrm{v}\right)=0.71 . \mathrm{C}_{18} \mathrm{H}_{20} \mathrm{~N}_{2} \mathrm{~S}_{2}$ : EIMS $\left(\mathrm{M}^{+} \bullet\right): 406$.

4.2.31. 3,4-Dicyano-2,2'-bithiophene (34). 2-Bromo-3,4-dicyanothiophene (31) (500.9 $\mathrm{mg}, 2.35 \mathrm{mmol})$ and 2-(tributylstannyl)thiophène $(1.754 \mathrm{~g}, 1.50 \mathrm{~mL}, 4.70 \mathrm{mmol})$ were dissolved in dry DMF $(20 \mathrm{~mL})$ under argon. To this solution was added $\mathrm{Pd}\left(\mathrm{PPh}_{3}\right)_{4}$ (250 mg) and the mixture was heated at $70-80^{\circ} \mathrm{C}$ for $2 \mathrm{~h}$. After cooling, $50 \mathrm{~mL}$ of saturated solution of $\mathrm{NH}_{4} \mathrm{Cl}$ was added and the mixture was extracted twice with $\mathrm{CH}_{2} \mathrm{Cl}_{2}$. The combined organic phases were washed twice with water and dried over magnesium sulfate. After filtration, the solvent was removed under vacuum. Purification of the residue by column chromatography on silica gel $\left(\mathrm{CH}_{2} \mathrm{Cl}_{2}\right)$ afforded $394 \mathrm{mg}(1.82 \mathrm{mmol})$ of 3,4-dicyano-2,2'-bithiophene (34) as a white solid. Yield: $77 \%$.

${ }^{1} \mathrm{H}$ NMR $\left(\mathrm{CDCl}_{3}\right): 7.83(\mathrm{~s}, 1 \mathrm{H}, \mathrm{H} 5), 7.68(\mathrm{dd}, 1 \mathrm{H}, J=1.14$ and $3.76 \mathrm{~Hz}, \mathrm{H}^{\prime}$ ), $7.54\left(\mathrm{dd}, 1 \mathrm{H}, J=1.14\right.$ and $\left.5.10 \mathrm{~Hz}, \mathrm{H}^{\prime}\right) 7.18(\mathrm{dd}, 1 \mathrm{H}$, 
$J=3.76$ and $\left.5.10 \mathrm{~Hz}, \mathrm{H}^{\prime}\right) .{ }^{13} \mathrm{C} \mathrm{NMR}\left(\mathrm{CDCl}_{3}\right): 148.7$ (C2), 133.8 (C5), $131.1\left(\mathrm{C}^{\prime}\right), 129.5,128.9,128.7\left(\mathrm{C}^{\prime}, \mathrm{C}^{\prime}, \mathrm{C}^{\prime}\right), 113.7,112.6,111.9,106.1$ (C3, C4, C6, C7). $\mathrm{Mp}=164-166^{\circ} \mathrm{C} . R_{f}\left(\mathrm{CH}_{2} \mathrm{Cl}_{2}\right)=0.64 . \mathrm{C}_{10} \mathrm{H}_{4} \mathrm{~N}_{2} \mathrm{~S}_{2}$ : EIMS $\left(\mathrm{M}^{+} \bullet\right): 216$.

4.2.32. 5'-Bromo-3,4-dicyano-2,2'-bithiophene (35). 3,4-Dicyano2,2'-bithiophene (34) $(152.3 \mathrm{mg}, 0.70 \mathrm{mmol})$ was dissolved in $\mathrm{CH}_{2} \mathrm{Cl}_{2}(10 \mathrm{~mL})$. Bromine $(78 \mu \mathrm{L}, 244.0 \mathrm{mg}, 0.75 \mathrm{mmol})$ was added dropwise. After stirring for $35 \mathrm{~min}$, the mixture was washed with a solution of $\mathrm{Na}_{2} \mathrm{~S}_{2} \mathrm{O}_{3}$ and with water. The organic layer was dried over $\mathrm{MgSO}_{4}$. After filtration, the solvent was removed under vacuum and purification by column chromatography on silica gel $\left(\mathrm{CH}_{2} \mathrm{Cl}_{2}\right)$ afforded 5'-bromo-3,4-dicyano-2,2'-bithiophene as a pale yellow solid ( $162 \mathrm{mg}, 0.55 \mathrm{mmol}$ ). Yield: $79 \%$.

${ }^{1} \mathrm{H} \mathrm{NMR}\left(\mathrm{CDCl}_{3}\right): 7.85(\mathrm{~s}, 1 \mathrm{H}, \mathrm{H} 5), 7.41\left(\mathrm{~d}, 1 \mathrm{H}, \mathrm{J}=4.01 \mathrm{~Hz}, \mathrm{H} 3^{\prime}\right), 7.14$ (d, $\left.1 \mathrm{H}, 4.01 \mathrm{~Hz}, \mathrm{H}^{\prime}\right) .{ }^{13} \mathrm{C} \mathrm{NMR}\left(\mathrm{CDCl}_{3}\right): 147.4$ (C2), 133.9 (C5), 132.4 (C2'), 131.5, $129.1\left(\mathrm{C}^{\prime}, \mathrm{C}^{\prime}\right), 117.4\left(\mathrm{C}^{\prime}\right), 113.8,112.4,111.7,106.4(\mathrm{C} 3$, C4, C6, C7). $\mathrm{Mp}=188-192{ }^{\circ} \mathrm{C} . R_{f}\left(\mathrm{CH}_{2} \mathrm{Cl}_{2}\right)=0.73 . \mathrm{C}_{10} \mathrm{H}_{3} \mathrm{Br}(79) \mathrm{N}_{2} \mathrm{~S}_{2}$ : EIMS $\left(\mathrm{M}^{+} \bullet\right): 294$.

4.2.33. 5-Bromo-3,4-dicyano-2,2'-bithiophene (36). 3,4-Dicyano2,2'-bithiophene (34) $(121.0 \mathrm{mg}, 0.56 \mathrm{mmol})$ was dissolved in dry THF $(30 \mathrm{~mL})$ under argon. The solution was cooled to $-80{ }^{\circ} \mathrm{C}$ and stirred during $10 \mathrm{~min}$, then LDA $(0.34 \mathrm{~mL}, 0.62 \mathrm{mmol})(1.8 \mathrm{M}$ in solution in THF/n-heptane/ethylbenzene) was added dropwise. The mixture was then stirred for $10 \mathrm{~min}$ and bromine $(58 \mu \mathrm{L}, 182.3 \mathrm{mg}$, $0.56 \mathrm{mmol}$ ) was slowly added. The mixture was stirred for 30 more min. After adding a saturated solution of $\mathrm{NH}_{4} \mathrm{Cl}(20 \mathrm{~mL})$, the solution was extracted with $\mathrm{CH}_{2} \mathrm{Cl}_{2}$. The organic layers were washed with a solution of $\mathrm{Na}_{2} \mathrm{~S}_{2} \mathrm{O}_{3}$ and dried over $\mathrm{MgSO}_{4}$. After filtration, the solvent was removed under vacuum. The residue was dissolved in $\mathrm{CH}_{2} \mathrm{Cl}_{2}$ and purified by column chromatography on silica gel $\left(\mathrm{CH}_{2} \mathrm{Cl}_{2} /\right.$ hexane $\left.1 / 1 \mathrm{v} / \mathrm{v}\right)$ to give a pale yellow solid $(110.0 \mathrm{mg}$, $0.37 \mathrm{mmol})$. Yield: $67 \%$.

${ }^{1} \mathrm{H} \mathrm{NMR}\left(\mathrm{CDCl}_{3}\right): 7.62\left(\mathrm{dd}, 1 \mathrm{H}, J=1.10\right.$ and $\left.3.77 \mathrm{~Hz}, \mathrm{H}^{\prime}\right), 7.55(\mathrm{dd}$, $1 \mathrm{H}, J=1.10$ and $\left.5.09 \mathrm{~Hz}, \mathrm{H} 5^{\prime}\right) 7.18\left(\mathrm{dd}, 1 \mathrm{H}, J=3.77\right.$ and $\left.5.09 \mathrm{~Hz}, \mathrm{H} 4^{\prime}\right) .{ }^{13} \mathrm{C}$ $\operatorname{NMR}\left(\mathrm{CDCl}_{3}\right)$ : $149.0(\mathrm{C} 2), 130.5\left(\mathrm{C2}^{\prime}\right), 129.9,129.1,128.8\left(\mathrm{C}^{\prime}, \mathrm{C}^{\prime}, \mathrm{C}^{\prime}\right)$, 122.1 (C5), 116.1, 111.9, 111.1, 105.9 (C3, C4, C6, C7). Mp $=196-198^{\circ} \mathrm{C}$. $R_{f}\left(\mathrm{CH}_{2} \mathrm{Cl}_{2}\right)=0.74 . \mathrm{C}_{10} \mathrm{H}_{3} \mathrm{Br}(79) \mathrm{N}_{2} \mathrm{~S}_{2}$ : EIMS $\left(\mathrm{M}^{+} \bullet\right): 294$.

4.2.34. 5-Bromo-5'octyl-3,4-dicyano-2,2'-bithiophene(37). 5-Bromo3,4-dicyano-2,2'-bithiophene (36) $(82.0 \mathrm{mg}, 0.28 \mathrm{mmol})$ and octanoyl chloride $(400 \mu \mathrm{L}, 380.0 \mathrm{mg}, 2.34 \mathrm{mmol})$ were dissolved in dry $\mathrm{CH}_{2} \mathrm{Cl}_{2}$ (15 mL). After adding in portions $\mathrm{AlCl}_{3}$ ( $750 \mathrm{mg}, 5.62 \mathrm{mmol}$ ), the mixture was refluxed for 3 days. After cooling, the reaction mixture was poured into cold $\mathrm{HCl}(2 \mathrm{M}, 100 \mathrm{~mL})$. After extraction with $\mathrm{CH}_{2} \mathrm{Cl}_{2}(3 \times 50 \mathrm{mlL})$, the combined organic layers were washed with brine $(2 \times 50 \mathrm{~mL})$ and water $(100 \mathrm{~mL})$. After drying over anhydrous $\mathrm{MgSO}_{4}$, the residue was purified by column chromatography on silica gel $\left(\mathrm{CH}_{2} \mathrm{Cl}_{2}\right)$. A yellow solid $(102.0 \mathrm{mg}, 0.24 \mathrm{mmol})$ was obtained in $86 \%$ yield.

${ }^{1} \mathrm{H}$ NMR $\left(\mathrm{CDCl}_{3}\right): 7.69\left(\mathrm{~d}, 1 \mathrm{H}, J=4.06 \mathrm{~Hz}, \mathrm{H}^{\prime}\right), 7.64(\mathrm{~d}, 1 \mathrm{H}$, $\left.J=4.06 \mathrm{~Hz}, \mathrm{H3}^{\prime}\right), 2.90$ (t, $\left.2 \mathrm{H}, J=7.31 \mathrm{~Hz},-\mathrm{CO}-\mathrm{CH}_{2}-\right), 1.75(\mathrm{~m}, 2 \mathrm{H}$, $\left.-\mathrm{CO}-\mathrm{CH}_{2}-\mathrm{CH}_{2}-\right), 1.34\left(\mathrm{~m}, 8 \mathrm{H},-\left(\mathrm{CH}_{2}\right)_{4}-\mathrm{CH}_{3}\right), 0.88(\mathrm{t}, 3 \mathrm{H}$, $\left.J=6.91 \mathrm{~Hz},-\mathrm{CH}_{3}\right) .{ }^{13} \mathrm{C} \mathrm{NMR}\left(\mathrm{CDCl}_{3}\right): 192.8(\mathrm{C}=\mathrm{O}), 147.4,147.2(\mathrm{C} 2$, $\left.\mathrm{C}^{\prime}\right), 136.5$ (C2'), 132.0, 129.1 (C3', C4'), 123.8 (C5), 116.7, 111.5, 110.8, 107.6 (C3, C4, C6, C7), 39.4 (-CO- $\mathrm{CH}_{2}-$ ), 31.6, 29.2, 29.0, 24.5, 22.6 $\left(-\left(\mathrm{CH}_{2}\right)_{5}-\mathrm{CH}_{3}\right), 14.1\left(-\mathrm{CH}_{3}\right) . \mathrm{Mp}=130-132{ }^{\circ} \mathrm{C} . R_{f}\left(\mathrm{CH}_{2} \mathrm{Cl}_{2}\right)=0.64$. $\mathrm{C}_{16} \mathrm{H}_{17} \mathrm{Br}(79) \mathrm{N}_{2} \mathrm{OS}_{2}$ : EIMS $\left(\mathrm{M}^{+} \cdot\right)$ : 420.

4.2.35. 5,5' -Dibromo-3', $4^{\prime}$-dicyano-2, $2^{\prime}: 5^{\prime}, 2^{\prime \prime}$-terthiophene (38). To a solution of $3^{\prime}, 4^{\prime}$-dicyano- $2,2^{\prime}: 5^{\prime}, 2^{\prime \prime}$-terthiophene $(12)(180.0 \mathrm{mg}$, $0.60 \mathrm{mmol})$ in $\mathrm{CH}_{2} \mathrm{Cl}_{2}(15 \mathrm{~mL})$, bromine $(100 \mu \mathrm{L}, 300 \mathrm{mg}$, $1.88 \mathrm{mmol}$ ) was added dropwise at room temperature. The mixture was then stirred for $1.5 \mathrm{~h}$. The precipitate formed was isolated by filtration and washed with methanol and hexane. After drying, a yellow solid ( $265 \mathrm{mg}, 0.58 \mathrm{mmol}$ ) was obtained in quantitative yield.

${ }^{1} \mathrm{H}$ NMR (DMSO- $d_{6}$ ): 7.53 (d, 2H, $J=4.02 \mathrm{~Hz}, \mathrm{H} 4, \mathrm{H} 4{ }^{\prime \prime}$ ), 7.29 (d, 2H, $J=4.04 \mathrm{~Hz}, \mathrm{H3}, \mathrm{H3}^{\prime \prime}$ ). ${ }^{13} \mathrm{C}$ NMR (DMSO- $d_{6}$ ): the solubility is too low for ${ }^{13} \mathrm{C}$ NMR measurements. $\mathrm{Mp}=254-256{ }^{\circ} \mathrm{C}$. $\mathrm{C}_{14} \mathrm{H}_{4} \mathrm{Br}(79)_{2} \mathrm{~N}_{2} \mathrm{~S}_{3}$ : EI-HRMS $\left(\mathrm{M}^{+} \bullet\right.$ ): calcd: 453.7903; found: 453.7914.

4.2.36. 5-Octyl-3,4-dicyano-2,2':5',2'-terthiophene (39). 5'-Bromo5-octyl-3,4-dicyano-2,2'-bithiophene (29) $(163.0 \mathrm{mg}, 0.40 \mathrm{mmol}$ ), $\mathrm{Pd}\left(\mathrm{PPh}_{3}\right)_{4}(60.0 \mathrm{mg}, 0.05 \mathrm{mmol})$ and 2-(tributylstannyl)thiophene $(224.0 \mathrm{~g}, 191 \mu \mathrm{L}, 0.6 \mathrm{mmol})$ were dissolved in dry toluene $(10 \mathrm{~mL})$ under argon. This mixture was then stirred at $105^{\circ} \mathrm{C}$ for $2 \mathrm{~h}$. After cooling, the mixture was directly purified by column chromatography on silica gel $\left(\mathrm{CH}_{2} \mathrm{Cl}_{2}\right)$ to afford the desired terthiophene $\mathbf{3 9}$ (155.0 mg, $0.38 \mathrm{mmol}$ ) as a yellow solid. Yield: $94 \%$.

${ }^{1} \mathrm{H} \mathrm{NMR}\left(\mathrm{CDCl}_{3}\right): 7.50\left(\mathrm{~d}, 1 \mathrm{H}, J=3.95 \mathrm{~Hz}, \mathrm{H}^{\prime}\right), 7.10(\mathrm{~d}, 1 \mathrm{H}, J=3.95$, $\left.\mathrm{H}^{\prime \prime}\right), 7.02\left(\mathrm{~m}, 2 \mathrm{H}, \mathrm{H}^{\prime \prime}, \mathrm{H} 4^{\prime}\right), 2.99\left(\mathrm{t}, 2 \mathrm{H}, \mathrm{J}=7.50 \mathrm{~Hz},-\mathrm{CH}_{2}-\mathrm{C}_{7} \mathrm{H}_{15}\right)$, $1.75\left(\mathrm{~m}, 2 \mathrm{H},-\mathrm{CH}_{2}-\mathrm{CH}_{2}-\mathrm{C}_{6} \mathrm{H}_{12}\right), 1.34\left(\mathrm{~m}, 10 \mathrm{H},-\left(\mathrm{CH}_{2}\right)_{5}-\mathrm{CH}_{3}, 0.89\right.$ (t, $\left.3 \mathrm{H}, \mathrm{J}=6.94 \mathrm{~Hz}, \mathrm{CH}_{3}\right) \cdot{ }^{13} \mathrm{C} \mathrm{NMR}\left(\mathrm{CDCl}_{3}\right): 156.1$ (C5), 145.3 (C2), 141.0 $\left(\mathrm{C}^{\prime}\right), 135.7$ (C5'), 129.9 (C2" $), 129.0,128.2,126.1,125.2,124.5$ (C3', C4', C3", C4", C5"), 113.1, 111.9 (C6, C7), 110.5 (C4), 104.4 (C3), 31.7, 31.0, 29.7, 29.1, 29.0, 28.9, $\left.22.6\left(\mathrm{CH}_{2}\right)_{7}-\mathrm{CH}_{3}\right), 14.1\left(\mathrm{CH}_{3}\right)$. $\mathrm{Mp}=71-73{ }^{\circ} \mathrm{C} . R_{f}\left(\mathrm{CH}_{2} \mathrm{Cl}_{2}\right)=0.79 . \mathrm{C}_{22} \mathrm{H}_{22} \mathrm{~N}_{2} \mathrm{~S}_{3}$ : EIMS $\left(\mathrm{M}^{+} \bullet\right): 410$.

4.2.37. 5-Octyl-5' -bromo-3,4-dicyano-2,2':5', $2^{\prime \prime}$-terthiophene (40). 5-Octyl-3,4-dicyano-2, $2^{\prime}: 5^{\prime}, 2^{\prime \prime}$-terthiophene (39) $(155.0 \mathrm{mg}$, $0.38 \mathrm{mmol})$ was dissolved in chloroform $(20 \mathrm{~mL})$ and $N$-bromosuccinimide (NBS) ( $101.5 \mathrm{mg}, 0.57 \mathrm{mmol}$ ) was added in portions at room temperature. After stirring for $16 \mathrm{~h}$ in dark, the mixture was washed twice with water. The organic layer was dried over $\mathrm{MgSO}_{4}$, filtrated, and then concentrated under vacuum. Purification by column chromatography on silica gel $\left(\mathrm{CH}_{2} \mathrm{Cl}_{2}\right.$ /petrolum ether $6 / 4$ $\mathrm{v} / \mathrm{v}$ ) afforded the desired brominated terthiophene $\mathbf{4 0}(156.0 \mathrm{mg}$, $0.32 \mathrm{mmol}$ ) as a yellow solid. Yield: $84 \%$.

${ }^{1} \mathrm{H} \mathrm{NMR}\left(\mathrm{CDCl}_{3}\right): 7.52\left(\mathrm{~d}, 1 \mathrm{H}, J=3.95 \mathrm{~Hz}, \mathrm{H3}^{\prime}\right), 7.31(\mathrm{dd}, 1 \mathrm{H}, J=1.09$ and $5.07 \mathrm{~Hz}, \mathrm{H}^{\prime \prime}$ ), $7.27\left(\mathrm{dd}, 1 \mathrm{H}, J=1.09\right.$ and $\left.3.68 \mathrm{~Hz}, \mathrm{H}^{\prime \prime}\right), 7.17(\mathrm{~d}, 1 \mathrm{H}$, $J=3.95 \mathrm{~Hz}, \mathrm{H} 4^{\prime}$ ), 7.06 (dd, $1 \mathrm{H}, J=3.68$ and $\left.5.07 \mathrm{~Hz}, \mathrm{H} 4^{\prime \prime}\right), 2.98(\mathrm{t}, 2 \mathrm{H}$, $\left.J=7.62 \mathrm{~Hz},-\mathrm{CH}_{2}-\mathrm{C}_{7} \mathrm{H}_{15}\right), 1.75\left(\mathrm{~m}, 2 \mathrm{H},-\mathrm{CH}_{2}-\mathrm{CH}_{2}-\mathrm{C}_{6} \mathrm{H}_{12}\right), 1.34(\mathrm{~m}$, $10 \mathrm{H},-\left(\mathrm{CH}_{2}\right)_{5}-\mathrm{CH}_{3}, 0.89\left(\mathrm{t}, 3 \mathrm{H}, J=6.69 \mathrm{~Hz}, \mathrm{CH}_{3}\right) .{ }^{13} \mathrm{C} \mathrm{NMR}\left(\mathrm{CDCl}_{3}\right)$ : 156.4 (C5), 145.0 (C2), $139.8\left(\mathrm{C}^{\prime}\right), 137.1\left(\mathrm{C}^{\prime}\right), 131.0\left(\mathrm{C}^{\prime \prime}\right), 130.2\left(\mathrm{C}^{\prime \prime}\right)$, 129.0, 125.3, $124.8\left(\mathrm{C}^{\prime}, \mathrm{C}^{\prime}, \mathrm{C}^{\prime \prime}\right), 113.0,112.9,111.8,110.5,104.7$ (C3, C4, C5", C6, C7), 31.7, 31.0, 29.8, 29.0, 28.9, $\left.22.6\left(\mathrm{CH}_{2}\right)_{7}-\mathrm{CH}_{3}\right), 14.1$ $\left(\mathrm{CH}_{3}\right) . \mathrm{Mp}=111-112^{\circ} \mathrm{C} . R_{f}\left(\mathrm{CH}_{2} \mathrm{Cl}_{2} /\right.$ petrolum ether $\left.6 / 4 \mathrm{v} / \mathrm{v}\right)=0.74$.

\section{Acknowledgements}

The authors would like to thank the Région Wallonne ETIQUEL project for financial support, Pr. Pascal Gerbaux from the Mass Spectrometry Center of the Université de Mons-Hainaut for mass spectrometry measurements and Pr. Claudine Buess-Hermann from the laboratory of analytic chemistry and interfaces chemistry (CHANI) of the Université Libre de Bruxelles for providing access to the electrochemical equipment. J. Cornil is a senior research fellow of the Belgian National Fund for Scientific Research (FNRS).

\section{Supplementary data}

NMR spectra, UV-vis spectra and cyclic voltammograms of compounds $\mathbf{1 a}, \mathbf{b}, \mathbf{2 a}, \mathbf{b}, \mathbf{3 a}, \mathbf{b}, \mathbf{4 a}, \mathbf{b}, \mathbf{5 a}, \mathbf{b}, \mathbf{6}$, and $\mathbf{7}$ are shown in Supplementary data. Supplementary data associated with this article can be found in online version at doi:10.1016/j.tet.2010.09.086.

\section{References and notes}

1. Mas-Torrent, M.; Rovira, C. Chem. Soc. Rev. 2008, 37, 827.

2. Allard, S.; Forster, M.; Souharce, B.; Thiem, H.; Scherf, U. Angew. Chem., Int. Ed. 2008, 47, 4070. 
3. Facchetti, A. Mater. Today 2007, 10, 28; Coakley, K. M.; McGehee, M. D. Chem. Mater. 2004, 16, 4533.

4. Chen, C. T. Chem. Mater. 2004, 16, 4389.

5. Murphy, A. R.; Fréchet, J. M. J. Chem. Rev. 2007, 107, 1066.

6. Anthony, J. E. Chem. Rev. 2006, 106, 5028.

7. Coropceanu, V.; Cornil, J.; Da Silva Filho, D. A.; Olivier, Y.; Silbey, R.; Brédas, J. L Chem. Rev. 2007, 107, 926

8. Halik, M.; Klauk, H.; Zschieschang, U.; Schmid, G.; Ponomarenko, S.; Kirchmeyer, S.; Weber, W. Adv. Mater. 2003, 15, 917.

9. De Leeuw, D. M.; Simenon, J.; Brown, A. R.; Einerhand, R. E. F. Synth. Met. 1997, $87,53$.

10. Rivnay, J.; Jimison, L. H.; Northup, J. E.; Toney, M. F.; Noriega, R.; Lu, S.; Marks, T. J.; Facchetti, A.; Salleo, A. Nat. Mater. 2009, 8, 952.

11. Yoon, M. H.; DiBenedetto, S. A.; Russel, M. T.; Facchetti, A.; Marks, T. J. Chem. Mater. 2007, 19, 4864.

12. Newman, C. R.; Frisbie, C. D.; Da Silva Filho, D. A.; Brédas, J. L.; Ewbank, P. C.; Mann, K. R. Chem. Mater. 2004, 16, 4436.

13. Yoon, M. H.; DiBenedetto, S. A.; Facchetti, A.; Marks, T. J. J. Am. Chem. Soc. 2005, 127, 1348.

14. Hapiot, P.; Demanze, F.; Yassar, A.; Garnier, F. J. Phys. Chem. 1996, 100, 8397.

15. Hide, F.; Greenwald, Y.; Wudl, F.; Heeger, A. J. Synth. Met. 1997, 85, 1255.

16. Demanze, F.; Cornil, J.; Garnier, F.; Horowitz, G.; Valat, P.; Yassar, A.; Lazzaroni, R.; Brédas, J. L. J. Chem. Phys. B 1997, 101, 4553.

17. De Oliveira, M. A.; Dos Santos, H. F.; De Almeida, W. B. Int. J. Ouantum Chem. 2002, 90, 603 .

18. Yassar, A.; Demanze, F.; Jaafari, A.; El Idrissi, M.; Coupry, C. Adv. Funct. Mater. 2002, 12, 699 .

19. Hergué, N.; Mallet, C.; Frère, P.; Allain, M.; Roncali, J. Macromolecules 2009, 42, 5593.

20. Barclay, T. M.; Cordes, A. W.; MacKinnon, C. D.; Oakley, R. T.; Reed, R. W. Chem. Mater. 1997, 9, 981.

21. Perepichka, I.; Perepichka, D. F. Handbook of Thiophene-based Materials Applications in Organic Electronics and Photonics;. Synthesis and Theory, 1st ed. Wiley: Chichester, West Sussex, UK, 2009; Vol. 1.

22. Vollhart, K. P. C.; Schore, N. E. Organic Chemistry: Structure and Function, 3rd ed.; Freeman W.H. and Compagny: Paris, Bruxelles, 1999.

23. Crayston, J. A.; Iraqi, A.; Mallon, P.; Walton, J. C. J. Chem. Soc., Perkin Trans. 2 1993, 1589.

24. MacDowell, D. W. H.; Wisowaty, J. C. J. Org. Chem. 1972, 37, 1712.

25. Nielsen, C. B.; Bjùrnholm, T. Org. Lett. 2004, 6, 3381.
26. Shen, P.; Zhao, B.; Huang, X.; Huang, H.; Tan, S. Eur. Polym. J. 2009, 45, 2726. 27. Wei, Y.; Yang, Y.; Yeh, J. M. Chem. Mater. 1999, 8, 2659.

28. Michaelides, M. R.; Hong, Y.; DiDomenico, S.; Bayburt, E. K., Jr.; Asin, K. E. Britton, D. R.; Lin, C. W.; Shiosaki, K. J. Med. Chem. 1997, 40, 1585.

29. He, M.; Zhang, F. J. Org. Chem. 2007, 72, 442.

30. Balandier, J. Y.; Belyasmine, A.; Sallé, M. Synthesis 2006, 17, 2815.

31. Parrish, J. P.; Flanders, V. L.; Floyd, R. J.; Jung, K. W. Tetrahedron Lett. 2001, 42, 7729.

32. Hassan, J.; Lavenot, L.; Gozzi, C.; Lemaire, M. Tetrahedron Lett. 1999, 40, 857.

33. Xie, Y.; Wu, B. M.; Xue, F.; Ng, S. C.; Mak, T. C. W.; Andy Hor, T. S. Organometallics 1998, 17, 3988.

34. Becke, A. D. J. Chem. Phys. 1993, 98, 5648; Lee, C.; Yang, W.; Parr, R. G. Phys. Rev $B$ 1988, 37, 785.

35. Frisch, M. J.; Trucks, G. W.; Schlegel, H. B.; Scuseria, G. E.; Robb, M. A.; Cheeseman, J. R.; Montgomery, J. A. J.; Vreven, T.; Kudin, K. N.; Burant, J. C.; Millam, J. M.; Iyengar, S. S.; Tomasi, J.; Barone, V.; Mennucci, B.; Cossi, M. Scalmani, G.; Rega, N.; Petersson, G. A.; Nakatsuji, H.; Hada, M.; Ehara, M. Toyota, K.; Fukuda, R.; Hasegawa, J.; Ishida, M.; Nakajima, T.; Honda, Y.; Kitao, O.; Nakai, H.; Klene, M.; Li, X.; Knox, J. E.; Hratchian, H. P.; Cross, J. B.; Bakken, V.; Adamo, C.; Jaramillo, J.; Gomperts, R.; Stratmann, R. E.; Yazyev, O.; Austin, A. J.; Cammi, R.; Pomelli, C.; Ochterski, J. W.; Ayala, P. Y.; Morokuma, K.; Voth, G. A.; Salvador, P.; Dannenberg, J. J.; Zakrzewski, V. G.; Dapprich, S.; Daniels, A. D.; Strain, M. C.; Farkas, O.; Malick, D. K.; Rabuck, A. D.; Raghavachari, K.; Foresman, J. B.; Ortiz, J. V.; Cui, Q.; Baboul, A. G.; Clifford, S.; Cioslowski, J.; Stefanov, B. B.; Liu, G.; Liashenko, A.; Piskorz, P.; Komaromi, I.; Martin, R. L.; Fox D. J.; Keith, T.; Al-Laham, M. A.; Peng, C. Y.; Nanayakkara, A.; Challacombe, M. Gill, P. M. W.; Johnson, B.; Chen, W.; Wong, M. W.; Gonzalez, C.; Pople, J. A. Gaussian 03, Revision B.03; Gaussian: Wallingford, CT, 2004.

36. Meier, H.; Stalmach, U.; Kolshorn, H. Acta Polym. 1997, 48, 379.

37. Ten Hoeve, W.; Wynberg, H.; Havinga, E. E.; Meijer, E. W. J. Am. Chem. Soc. 1991, 113, 5887.

38. Pina, J.; Burrows, H. D.; Becker, R. S.; Dias, F. B.; Maçanita, A. L.; Seixas de Melo, J. J. Phys. Chem. B 2006, 110, 6499.

39. Gierschner, J.; Cornil, J.; Egelhaaf, H. J. Adv. Mater. 2007, 19, 173.

40. DiCesare, N.; Belletête, M.; Donat-Bouillud, A.; Leclerc, M.; Durocher, G. Macromolecules 1998, 31, 6289.

41. Šolc, R.; Lukeš, V.; Klein, E.; Griesser, E.; Kelterer, A. M. J. Phys. Chem. A 2008, 112, 40931.

42. Dal Colle, M.; Cova, C.; Distefano, G.; Jones, D.; Modelli, A.; Comisso, N. J. Phys. Chem. A 1999, 103, 2828 